\title{
RETOS DEL DERECHO PENAL GLOBAL *
}

\author{
Fernando Navarro Cardoso **
}

Resumen: La globalización económico-financiera ha expandido sus efectos, alcanzando al Derecho, en general, y al Derecho Penal, en

Recibido: junio 2020. Aceptado: octubre 2020

* Este trabajo se incardina en el marco del Proyecto de Investigación "Hacia un modelo de justicia social: alternativas político-criminales", financiado por el Ministerio de Ciencia, Innovación y Universidades del Gobierno de España para los años 2019-2021 (RTI2018-095155A-C22).

Tiene su origen en la conferencia de clausura impartida en el marco del Segundo Congreso Internacional Nuevas fronteras del Derecho Penal: ciberdelincuencia, crimenes corporativos y cleptocracia. El título era casi idéntico (Los retos del Derecho Penal global), desapareciendo ahora el artículo, con la connotación semántica que ello conlleva de abandono de toda vocación de tratamiento exhaustivo y agotador del tema; aunque "obliga" a formular un número considerable de digresiones. Fue organizado por la Universidad Católica de Bogotá, y celebrado los días 31 de octubre y 1 de noviembre de 2019 en Bogotá (Colombia). Dejo constancia de mi agradecimiento a la Profa. Dra. Paula Rosa Ramírez Barbosa por la amable invitación y encargo, así como por la magnífica organización del evento.

** Titular de Derecho Penal ORCID ID: https://orcid.org/0000-0001-5316-3645 Facultad de Ciencias Jurídicas de la Universidad de Las Palmas de Gran Canaria. Calle Farmacéutico Enrique Arroyo, 8, 35017 Las Palmas de Gran Canaria, Las Palmas. Email: fernando.navarro@ulpgc.es 
particular. Varias de sus consecuencias deben recibir una valoración positiva, pero, al mismo tiempo ha generado o propiciado otras cuya evaluación debe ser sumamente negativa. Algunas de ellas, como la desregulación regulada y alguna de las derivas de sus manifestaciones (caso de los programas de cumplimiento o compliance programs, producto de la responsabilidad penal de las personas jurídicas), son el objeto central del presente trabajo, si bien se ha hecho necesario un importante esfuerzo delimitador previo, también desde la Criminología.

Palabras claves: globalización, criminología global, derecho penal global, desregulación regulada, responsabilidad penal de las personas jurídicas.

\title{
CHALLENGES OF GLOBAL CRIMINAL LAW
}

\begin{abstract}
The economical-financial globalization has expanded its effects, reaching the Law field in general and the Criminal Law in particular. Some of its consequences can be received with a positive appraisal, but at the same time it has generated others, which assessment must be exceedingly negative. Some of these consequences, as the regulated deregulation of laws and some of its derivation manifestations (case of compliance programs, result of the criminal responsibility of the legal entity), are the central subject in this work, although it has become necessary an important previous effort to delimit it, also from the Criminal Law.

Keywords: Globalization, Global Criminology, Global Criminal Law, Regulated deregulation, Criminal responsibility from Legal Entities.
\end{abstract}

\section{Introducción}

La expresión Derecho Penal global es un modo de sintetizar lo que se diga en torno al papel o a la situación del Derecho Penal en el contexto de la globalización, y se ha dicho mucho. Bien es verdad que últimamente se está volviendo sobre este tema por razones diversas, en algunas de las cuales me voy a detener en estas páginas. 
Como cuestión epistemológica previa, creo que podemos convenir lo que es «Derecho Penal», aunque sea desde una perspectiva político-criminal y no dogmática, haciendo un esfuerzo de comunión entre los llamados pensamiento problemático y pensamiento sistemático.

Conste que esto ya es un primer esfuerzo para situar estas reflexiones en un marco global; un marco de interrelación que, por otro lado, en absoluto debe merecernos una valoración negativa ${ }^{1}$. De este modo, sea desde el mundo del common law (o derecho anglosajón) o desde el mundo del civil law (o derecho continental), aceptando esta nomenclatura, aunque solo sea por razones pedagógicas, todos rápidamente podemos convenir el objeto del debate: un juicio de reproche penal por la realización de una conducta (típica) voluntaria y culpable ${ }^{2}$.

No sucede lo mismo con «globalización». No hay consenso respecto de ninguno de los elementos de análisis: ni en relación al concepto, ni a su cronología, ni a sus consecuencias. Dice Beck que "globalización es a buen seguro la palabra (a la vez eslogan y consigna) peor empleada, menos definida, probablemente la menos comprendida, la más nebulosa y políticamente la más eficaz de los últimos $-\mathrm{y}$ sin duda también de los próximos- años"3. Lo cierto es que, como apunta Steger, "los investigadores no solo mantienen opiniones dispares sobre la definición adecuada de globalización, sino que también discrepan con respecto a la escala, la causalidad, la cronología, el impacto, las trayectorias o los

1 Como dice acertadamente VOGEL, J.: «Derecho penal y globalización», Anuario de la Facultad de Derecho de la Universidad Autónoma de Madrid, $\mathrm{n}^{\circ}$ 9, 2005, p. 124, creer en la supremacía de un modelo solo es un acto de fe en tanto cuestión ideológica.

2 Vid. DONDÉ MATUTE, J.: «Elementos del Common Law en el Derecho Penal Internacional», Revista Penal México, nº 3, 2012, pp. 95 y ss.

3 BECK, U.: ¿Qué es la globalización? Falacias del globalismo, respuestas a la globalización, Paidós, Barcelona, 1998, p. 40. 
resultados políticos"4. Tal es así que, como señala Twining, la literatura en torno a la globalización es casi tan confusa como los procesos que busca interpretar ${ }^{5}$.

De entrada, en efecto, no hay consenso sobre el propio concepto, pues aunque no cabe duda alguna de que «globalización» es la expresión generalizada, hay quienes prefieren recurrir a «mundialización» ${ }^{6}$ o a «glocalización» ${ }^{7}$, entre otras.

Esa dificultad se explica, en parte, porque es un fenómeno poliédrico, de suerte que son muchas las perspectivas desde las que puede ser analizado (desde la economía, el derecho, la ética, la filosofía, la sociología, la politología, la geografía, etc.).

No se nos ocultan, obviamente, las razones ideológicas que contribuyen a sostener una determinada concepción, y no otra, del fenómeno. De hecho, Bauman contrapone globalización y universalización: el primero tiene que ver con el poder de una minoría sobre una mayoría en un mundo desigual, cada vez más porque ese poder se ejercita para satisfacer los intereses de la minoría, y no para solventar las necesidades de la inmensa mayoría. El segundo es una aspiración: precisamente la que consiste en lograr un mundo más equilibrado, menos desigual ${ }^{8}$.

4 STEGER, M.B.: Globalización. Una breve introducción, Antoni Bosch editor, Barcelona, 2019, p. 22.

5 TWINING, W.: Derecho y Globalización, Siglo del Hombre, Bogotá, 2003, p. 119.

6 Por ejemplo, CAPELLA HERNÁNDEZ, J.R.: «Estado y derecho ante la mundialización: aspectos y problemáticas generales», Estudios de Derecho Judicial, n ${ }^{\circ} 16,1999$, pp. 85 y ss.

7 ROBERTSON, R.: «Glocalización: tiempo-espacio y homogeneidad-heterogeneidad», en J.C. Monedero Fernández-Gala (coord.), Cansancio del Leviatán: problemas políticos de la mundialización, Trotta, Madrid, 2003, pp. 261 y ss.

8 Vid. BAUMAN, Z.: La globalización: consecuencias humanas, Fondo de la Cultura Económica, México, 2005, ya el primer capítulo o ensayo, «Tiempo y clase», pp. 3 y ss. 
En todo caso, como sostiene Vogel ${ }^{9}$, no es un concepto netamente jurídico y, por tanto, no le corresponde a un jurista definirlo -y seguramente menos a un penalista, puede añadirse-.

Desde un punto de vista descriptivo, si seguimos de nuevo a Vogel, comprendería lo siguiente ${ }^{10}$ :

"- (económicamente) la génesis de mercados globales en los que los agentes económicos -en particular, las empresas transnacionales en cuanto global players-en principio se mueven con libertad a escala mundial, y en los que, en principio, capital, trabajo, bienes y servicios pueden moverse libremente, lo que es posible gracias al avance técnico (tecnología de transportes, de información y comunicaciones);

- (en el plano político descriptivo) la pérdida de relevancia política (mundial) que sufren los Estados nacionales (the breaking of nations), y la génesis de mecanismos de gobierno global (global governance);

- (en el plano político normativo) la orientación política con base en los intereses del mundo en su conjunto, la humanidad, y no en intereses nacionales;

- (desde el punto de vista general objetivo) la «aproximación del mundo», la génesis de una comunidad de destino global con los tres subaspectos de una comunidad de la violencia (desde la perspectiva del autor), una comunidad de necesidad y sufrimiento (desde la perspectiva de la víctima) y una comunidad de cooperación;

- (desde el punto de vista general subjetivo) la creciente conciencia del mundo como un todo, la génesis de una ética mundial".

Rápidamente podemos percibir el esfuerzo realizado en pro de una descripción lo más neutra posible. Por desta-

9 VOGEL, J.: «Derecho penal y globalización», cit., p. 114.

10 Ibidem, pp. 114 y 115. 
car solo un aspecto a modo de ejemplo, resultará bien difícil encontrar consenso en torno a la idea de que la globalización económica, ni en su génesis, pensó en un mercado global donde el trabajo pudiese moverse libremente. En el mejor de los casos, hace mucho tiempo que no es así. De hecho, precisamente sobre esta cuestión del movimiento de trabajadores volveré luego por su relevancia en el binomio globalizaciónDerecho Penal.

Respecto a los períodos, es por todos conocida, de igual modo, la falta de acuerdo sobre este extremo. Hay quienes sitúan la "globalización 1.0» en el descubrimiento del Nuevo Mundo por Cristóbal Colón, caso de Friedman ${ }^{11}$. Puede haber más consenso en situar un período que comprendería desde los Acuerdos de Bretton Woods en 1944 (que suponen el nacimiento del Banco Mundial y del Fondo Monetario Internacional) hasta la crisis mundial de 2008. Y parece que hoy asistimos a una nueva etapa, que algunos llaman incluso «desglobalización». Se caracteriza, en lo que aquí conviene, por la necesidad de introducir elementos correctores que amortigüen algunos de los efectos más perversos $-\mathrm{O}$ negativos, en todo caso- de la globalización. Como dijo en el Foro Mundial de Davos Marc Benioff, presidente de Salesforce: "Este capitalismo, tal como lo hemos conocido, está muerto" 12 .

11 FRIEDMAN, T.L.: La tierra es plana. Breve historia del mundo globalizado del siglo XXI, Ediciones Martínez Roca, Madrid, 2006, p. 19. Para una visión distinta, cfr. STEGER, M.B.: Globalización. Una breve introducción, cit., passim; y p. 14, donde le atribuye a aquel, por su libro El Lexus y el olivo, y a OHMAE, K. por su obra El fin del estado-nación, el haber dejado en los lectores, desgraciadamente, una "simplista impresión" de la globalización.

12 Vid. las siempre recomendables reflexiones del Jefe de Opinión de $E l$ Confidencial, HERNÁNDEZ, E.: «Un multimillonario advierte: "Todos lo sabemos, este capitalismo está muerto"», Postpolítica [blog], 17 de octubre de 2019 [En línea: https://blogs.elconfidencial.com/ espana/postpolitica/].

Obviamente, ese fenómeno inverso al de la globalización -esto es, a aquel en el que en especial la economía (si bien también la sociedad, 
Y, qué duda cabe, esta desglobalización se ha hecho más visible con motivo de la pandemia por el coronavirus, y a determinados niveles, ha acelerado este proceso.

El filósofo político británico John Gray sostiene que la hiperglobalización de las últimas décadas se acaba. El capitalismo neoliberal está en quiebra, de modo que asistimos a un punto de inflexión histórico.

Fabricar mascarillas y respiradores en local no es solo una demanda coyuntural por un cierre de tráfico, sino que sirve como ejemplo de la hiperdependencia generada por largas cadenas de abastecimiento deslocalizadas en nuestros entornos, pero muy localizadas en otro. China es, en este sentido, paradigmática.

Dice Gray: "Esto no significa pasar a un localismo a pequeña escala. La población humana es demasiado numerosa para que la autosuficiencia local sea viable, y la mayor parte de la humanidad no está dispuesta a regresar a las comunidades pequeñas y cerradas de un pasado más distante. Pero la hiperglobalización de las últimas décadas tampoco va a volver"13.

En síntesis, al menos puede constatarse que estamos asistiendo a una nueva etapa caracterizada por la necesidad de introducir elementos correctores que amortigüen algunos de los efectos más perversos de la globalización. Conocer

la política y la cultura) vivió una etapa de interacción, interrelación e interdependencia mundiales, dicho sea en los términos más asépticos posibles-, que representa una vuelta, de nuevo, a la relevancia o preponderancia de lo local o regional, tiene unas razones geoestratégicas y sociopolíticas indiscutibles, que no tienen que ver, directa e inmediatamente, con aquellos loables criterios correctores. Y tiene también unas expresiones políticas contundentes: el American first de Donald Trump y el Brexit son claros ejemplos.

13 Gray, J.: "Adiós globalización, empieza un mundo nuevo. O por qué esta crisis es un punto de inflexión en la historia», Diario El País, 12 de abril de 2020 [En línea: www.elpais.com. Último acceso: agosto de 2020]. 
esos efectos contribuye, de manera decidida, a perfilar el objeto de estudio, para lo cual acudimos a la delimitación que se hace desde la Criminología.

\section{La criminología global y los delitos globales}

\subsection{La «criminología global»}

Como se acaba de decir, lo que interesa ahora destacar de este último ciclo es precisamente que existe un acuerdo amplio acerca de la necesidad de corregir al menos algunas de las más graves disfuncionalidades generadas por la globalización, o si se prefiere, de hechos negativos que aquella promovió o, en su caso, aceleró.

En ese contexto hay que situar las nuevas propuestas que provienen desde la Criminología crítica, que interesan destacar, no tanto por la relevancia de lo que se plantea, que indudablemente la tiene, como porque sirven para delimitar negativamente el objeto de este trabajo. Dicho de otro modo, la globalización ha provocado o ha favorecido consecuencias negativas de distinta naturaleza; y cierto enfoque criminológico sostiene que deben ser objeto de estudio por la Criminología, en una nueva dimensión de la misma; si bien, de todas aquellas derivaciones nefastas, aprovecho este epígrafe para abordar una (propia del Derecho Penal global).

Constata Ferrajoli ${ }^{14}$ que el objeto tradicional de la Criminología ha sido la criminalidad individual. Cita a Morrison porque es quien ha formulado una serie de reflexiones críticas hacia la Criminología, de tal calibre que, incluso, se ha llegado a sostener que "la hiere y, si bien no le

14 FERRAJOLI, L.: «Criminología, crímenes globales y Derecho Penal: el debate epistemológico en la Criminología contemporánea», Revista Crítica Penal y Poder, $\mathrm{n}^{\circ}$ 4, 2013, pp. 1 y ss.; el mismo, «Criminalidad y globalización», Boletín Mexicano de Derecho Comparado, nº 115, 2006, pp. 301 y ss. 
da el tiro de gracia, al menos abre una brecha que bien podría desangrarla en no mucho tiempo"15. Dando por seguro que eso no va a suceder, y que tampoco era esa la finalidad de sus reflexiones, sostiene este criminólogo neozelandés que el objeto de la Criminología ha sido la conducta desviada en el contexto de lo que él denomina "espacio civilizado" (construido a partir del «orden civilizado» de Hobbes ${ }^{16}$ ). Este es muy distinto "del que es propio de los confines de la civilización habitados por la barbarie", así denominado el otro espacio por los autores de la última traducción al español del trabajo de Morrison y de un magnífico Estudio Preliminar que lo acompaña ${ }^{17}$.

Ese «espacio civilizado» queda nítidamente delimitado a partir de dos preguntas claves, una que formula Morrison, ¿dónde estuvo la criminología mientras se producían los cientos de crímenes masivos de Estado desde mediados del siglo XIX hasta nuestros días?; y otra que formulan Bernal, Cabezas, Forero, Rivera y Vidal, ¿qué tiene que decir la criminología frente a las catástrofes terribles del hambre, la sed, las enfermedades, la devastación ambiental, causados por el actual anarco-capitalismo y el mercado financiero sin reglas? A esas dos constelaciones de crímenes añaden estos autores, en el propio interior del «espacio civilizado», los ataques a los derechos sociales y a los derechos de los trabajadores, provocados, en palabras de Ferrajoli, por las políticas neoliberales impuestas a los gobiernos por los mercados financieros ${ }^{18}$.

15 VIDAL TAMAYO, I.A.: «Recensión a Criminología, civilización y nuevo orden mundial», de W. Morrison, cit., Revista Crítica Penal y Poder, $\mathrm{n}^{\circ} 3$, 2012, p. 142.

16 MORRISON, W., Criminología, civilización y nuevo orden mundial, Anthropos, Barcelona, 2012, p. 18.

17 BERNAL SARMIENTO, C.E.; CABEZAS CHAMORRO, S.; FORERO CUELLAR, A.; RIVERA BEIRAS, I.; VIDAL TAMAYO, I.: «Estudio Preliminar», en Morrison, W., Criminología, civilización y nuevo orden mundial, Anthropos, Barcelona, 2012, pp. XXV y ss., XXVI.

18 FERRAJOLI, L.: «Criminología, crímenes globales y Derecho Penal...», cit., p. 3. 
Responde a esas preguntas el profesor italiano advirtiendo que claro que pueden constatarse una serie de crímenes. Propone que la Criminología (crítica, que él asocia con aquella que se independiza del Derecho Penal; esto es, que no está supeditada a él ${ }^{19}$ ) identifique como tales, en concreto como crímenes de masa contra la humanidad, a "las agresiones a los derechos humanos y a los bienes comunes realizados por los Estados y por los mercados" ${ }^{20}$. Llegados a este punto hace una distinción. Por un lado, los "crímenes de Estado", en los que incluye al genocidio, a los crímenes de guerra y a los crímenes contra la humanidad, y que deben ser objeto de la justicia penal. Por otro, los "crímenes del sistema", donde se encuentran, por ejemplo, "las masacres provocadas por la globalización capitalista sin reglas y que muchas veces son reconocidos como crímenes aunque no siempre son susceptibles de ser sancionados o castigados por la lógica del derecho penal" ${ }^{21}$; en definitiva, los crímenes contra los migrantes y contra los derechos humanos.

A ese último grupo, los crímenes del sistema, los llama también "crímenes globales". En lo que ahora interesa, admite Ferrajoli que no son configurables como delitos. Y pone un ejemplo que nos podríamos atrever a calificar de paradigmático: la legislación contra la inmigración clandestina, aprobada en Italia como en otros muchos países. Asume que nunca podrá ser configurada como delito. No obstante, sigue diciendo, "leyes de este tipo son las responsables de la silenciosa masacre de miles de inmigrantes que son rechazados día tras día en nuestras fronteras" ${ }^{\prime 2}$.

19 Ibidem, pp. 3 y 4. Vid., también, ZAFFARONI, E.R.; DIAS DOS SANTOS, I.: La nueva crítica criminológica. Criminología en tiempos de totalitarismo financiero, Ediar, Buenos Aires, 2019.

20 FERRAJOLI, L.: «Criminología, crímenes globales y Derecho Penal...», cit., p. 3.

21 Ibidem, p. 7.

22 Ibidem. 
En la raíz de estos crímenes encuentra la abdicación de lo público, un vacío de lo público, que tiene mucho que ver con la asimetría entre el carácter sustancialmente local de los poderes locales frente al carácter global de los poderes económicos y financieros. Tal es así, que afirma que ya no tenemos un gobierno público y político de la economía, sino que lo que ahora tenemos es el gobierno privado y económico de la política $^{23}$. Y donde, añadimos, el Derecho, en parte, ha dejado de ser el instrumento al servicio del interés general, para pasar a estar al servicio tutelador de esos intereses privados. En este mismo sentido se pronuncia, de manera diáfana también, entre otros muchos, Gracia Martín: "Los estados nacionales han claudicado ante los poderes económicos internacionales con la adopción de políticas ultraliberales y con la dotación de cobertura jurídica a los intereses de dichos poderes"24.

Por resultar tan sumamente ilustrativo, y porque entronca directa e inmediatamente con las reflexiones centrales de este trabajo, reproducimos las siguientes reflexiones de Ferrajoli ${ }^{25}$ :

"No son más los Estados, es decir, los gobiernos y los parlamentos elegidos democráticamente, que con sus políticas controlan los mercados y el mundo de los negocios, imponiendo sus reglas, límites y limitaciones en aras de la protección del interés general y de los derechos fundamentales de las personas, sino que ahora son los mercados, es decir unas pocas decenas de miles de especuladores financieros y algunas agencias privadas de calificación, que controlan y gobiernan a los estados, imponiendo

23 Ibidem, p. 8 (la frase no es textual, ni está en cursivas en el original).

24 GRACIA MARTÍN, L.: «Criminalidad de la globalización y Derecho penal», en C.M. Romeo Casabona (ed.), Biotecnología, desarrollo y justicia, Comares, Granada, 2008, p. 25.

25 FERRAJOLI, L.: «Criminología, crímenes globales y Derecho Penal...», cit., pp. 8 y 9. 
sus políticas anti-democráticas y anti-sociales en beneficio de intereses privados y especulativos y de la búsqueda de los máximos beneficios".

Ferrajoli, en última instancia, refiere una "Criminología global» que tiene como objeto de estudio el «delito global», entendiendo por este la criminalidad del poder, pero donde el poder público está cedido, ha claudicado ante ciertos poderes privados, producto de la hegemonía de determinadas políticas.

\subsection{Los «delitos globales». inmigración y aporofobia}

Antes de abandonar este ámbito, quisiera dejar apuntada alguna reflexión en relación con esta cuestión, pues atañe directamente al tema del trabajo: retos del Derecho Penal provenientes de la incidencia de la globalización.

En primer lugar, cabría fijar unas diferencias entre un delito internacional y un delito global. El primero sería aquel que tutela bienes jurídico-penales generales o universales ${ }^{26}$. Ejemplos paradigmáticos son, en mi opinión, los delitos de lesa humanidad (art. $607 \mathrm{CP}$ español) ${ }^{27}$; y, en opinión de Berdugo Gómez de la Torre, el soborno internacional, en tanto protege un bien jurídico-penal de esa naturaleza ${ }^{28}$. El segundo, el delito global, se caracterizaría porque su objeto de tutela sea de naturaleza individual o colectiva, resulta globalmente amenazado de modo grave (grave injusto y grave culpabilidad). Dicho de otro modo, el delito internacional lo sería en razón de su objeto de tutela, mientras que el delito global lo sería en atención a la fuente del peligro

26 Vid. alguna referencia en el epígrafe siguiente.

27 Vid. NAVARRO CARDOSO, F.: «Vallejo Nágera, "los niños perdidos del Franquismo" y los crímenes contra la humanidad", en J.C. Ferré Olivé (dir.), El derecho penal de la posguerra, Tirant lo Blanch, Valencia, 2016, pp. 339 y ss., 365 y nota 72.

28 BERDUGO GÓMEZ DE LA TORRE, I.: «El soborno internacional: normas, obstáculos y propuestas», Derecho \& Sociedad, n 52, 2019, pp. 165 y ss., 177. 
para dicho objeto, así como a la gravedad del ataque ${ }^{29}$. Y ello con independencia del posible carácter transnacional, que en muchas ocasiones concurriráa ${ }^{30}$.

Convenimos, de entrada, con Schünemann en que existen grupos de casos que más que permitirnos hablar de Derecho Penal globalizado, nos convendría hablar de Derecho Penal imperialista, colonialista, es decir, producto del colonialismo y del imperialismo. Pone dos claros ejemplos, el Derecho Penal de las drogas y el de la corrupción ${ }^{31}$. Desde luego lo son, de igual modo, el blanqueo de capitales y la financiación del terrorismo. Sin poner en tela de juicio la rotunda necesidad de luchar, también penalmente, a favor de la salud pública, de la salud democrática y de la salud económico-financiera, coincidimos en lo esencial con él. De hecho, su denuncia la tratamos más adelante, porque es uno de los objetos de este trabajo (aunque es cierto que donde él ve el imperialismo norteamericano, puede verse el impe-

29 Vid. algunas referencias expresas en GRACIA MARTÍN, L.: «Criminalidad de la globalización y Derecho penal», cit., pp. 34 a 37.

30 Para SPANGERBER BOLÍVAR, M.: «El Derecho penal del riesgo globalizado. Desafíos para un Derecho penal legítimo y trasnacionalmente efectivo», Revista de Derecho (Publicación de la Facultad de Derecho de la Universidad Católica de Uruguay), $\mathrm{n}^{\circ}$ 15, 2017, pp. 257 y ss., p. 268, un Derecho Penal moderno, que esté a la altura de las circunstancias, tiene que aspirar a convertirse en un Derecho Penal globalizado, lo que equivale, según este autor, a un Derecho Penal efectivo trasnacional. Cfr. GRACIA MARTÍN, L.: "Criminalidad de la globalización y Derecho penal», cit., p. 40, quien advierte, críticamente, que la doctrina sobredimensiona el contenido de lo que debe ser considerado el Derecho Penal de la globalización. Por ello, excluye la delincuencia transnacional, por ejemplo, en tanto no es un producto típico de aquella. No obstante, parece hacer coincidir el delito internacional y el delito global (p. 41). En igual sentido, QUINTERO OLIVARES, G.: «La globalización y el Derecho Penal: un cajón de sastre conceptual», en A. Galán Muñoz, S. Mendoza Calderón (dirs.), Globalización y lucha contra las nuevas formas de criminalidad transnacional, Tirant lo Blanch, Valencia, 2019, pp. 24 a 27.

31 SCHÜNEMANN, B.: «Das Strafrecht im Zeichen der Globalisierung», Goltdammer's Archiv für Strafrecht (5), 2003, pp. 299 y ss., 306 y ss. 
rialismo de organizaciones internacionales privadas, si bien estas velan también por los concretos intereses de algún o algunos países ${ }^{32}$ ).

Somos muchos los que coincidimos que el Derecho Penal global, y en su caso, el delito global, hay que vincularlo a la hegemonía de determinadas políticas, las cuales han producido auténticas debacles en cuestiones esenciales, en cuya defensa debiéramos sentirnos todos convocados. En esta línea, el cambio climático y la migración son, con seguridad, dos de las más graves pandemias del siglo XXI

Ejemplo por antonomasia de delito global en el sentido referido sería la actividad de promoción de la migración ilegal (con los matices normativos necesarios para que la conducta no presente ningún déficit de injusto material); y lo es incluso para quienes, como Vogel, tienen una visión crítica hacia la categoría Derecho Penal global, entendida en el sentido antes apuntado de aglutinadora de las consecuencias más devastadoras de la globalización ${ }^{34}$. Como indica

32 Vid., por todos, STIGLITZ, J.E.: El malestar en la globalización, Taurus, Madrid, 2002, ya en el Prólogo, pp. 11 a 19.

33 Donde la actual crisis sanitaria mundial no debiera hacernos perder de vista esas otras crisis, sin que se nos escapen las interrelaciones entre ellas. Sin ir más lejos, el parón mundial generado por la pandemia ha provocado una importante reducción de las emisiones de $\mathrm{CO}_{2}$. Vid. DÍAZ, T.: «La pandemia provoca la mayor reducción de $\mathrm{CO}_{2}$ de la historia», Diario elEconomista.es, 30 de abril de 2020 [En línea: https:// www.eleconomista.es. Último acceso: agosto de 2020].

34 VOGEL, J.: «Derecho penal y globalización», cit., p. 116: "Nadie debe cerrar los ojos frente a los lados oscuros de la globalización, de indudables efectos criminógenos. La presión migratoria desde regiones que cabe calificar de perdedoras en la globalización hacia las regiones que ganan con ella produce criminalidad de emigrantes y de tránsito oculto de fronteras, llegando hasta el tráfico de personas". Aunque pueda resultar equívoca la expresión "criminalidad de emigrantes», doy por supuesto que este lúcido y malogrado colega alemán no está criminalizando a las víctimas de la migración forzada producto de la globalización económica, en una suerte de elevación a la categoría de delito de la infracción administrativa consistente en el tránsito ilícito (oculto) de fronteras. 
Terradillos Basoco ${ }^{35}$, hay que tener presente, respecto a las grandes corporaciones transnacionales -las que materializan la globalización económica-, que la descriminalización de comportamientos de explotación laboral condiciona el flujo de inversiones (y viceversa, el flujo de inversiones condiciona las opciones político-criminales). Y ello es necesario en la actividad de deslocalización empresarial e industrial porque busca los entornos locales más favorables (no solo en términos laborales, sino también fiscales). Y respecto de los Estados, en tanto asumen la tarea de garantizar la competitividad de las empresas, han de mantener, siquiera sea indirectamente, sus actividades, de modo que deben relajar el control sobre las mismas, a la vez que han de asumir los costes de la libre disponibilidad de la mano de obra. El resultado no puede ser otro que el descrito: la globalización genera un intervencionismo estatal frente a sujetos y modalidades de conducta que perturban el funcionamiento de los mercados globalizados, como es la migración ilegal de personas pobres desde el tercer hacia el primer mundo ${ }^{36}$.

35 TERRADILLOS BASOCO, J.: «Globalización, administrativización y expansión del Derecho penal económico», Nuevo Foro Penal, $\mathrm{n}^{\circ} 70$, 2006, pp. 92 y ss.

36 La literatura penal acerca de la inmigración es inabarcable, y son muy diversas las cuestiones a tratar. Teniendo eso en cuenta, pueden citarse, en otros muchos trabajos, BOZA MARTÍNEZ, D.: La expulsión de personas extranjeras condenadas penalmente, Aranzadi, Cizur Menor, 2016; DE GIORGI, A.: «Control de la inmigración, post-fordismo y menor elegibilidad» Crítica penal y poder, $\mathrm{n}^{\circ}$ 2, 2012, pp. 139 y ss.; DONINI, M.: «El ciudadano extracomunitario: de "objeto material" a "tipo de autor" en el control penal de la inmigración», Revista Penal México, nº 4, 2013, pp. 35 y ss.; GARCÍA ESPAÑA, E.: «La expulsión como sustitutivo de la pena de prisión en el Código Penal de 2015», Revista electrónica de Ciencia Penal y Criminología, $\mathrm{n}^{\circ}$ 18, 2016, pp. 1 y ss.; GUISASOLA LERMA, C.: «Reformas penales y tendencias político-criminales en materia de inmigración», La Ley Penal, $n^{\circ}$ 67, 2010, pp. 1 y ss.; MARTÍNEZ ESCAMILLA, M.: «La criminalización de la solidaridad», Crítica penal y poder, ${ }^{\circ} 18,2019$, pp. 8 y ss.; MIRÓ LLINARES, F.: «Política comunitaria de inmigración y Política criminal en España», Revista Electrónica de Ciencia Penal y Criminología, 
Ahondando en esa idea, se hace un uso perverso del sistema punitivo para el logro de ciertos fines políticos y estratégicos respecto de los cuales el Derecho Penal debiera declararse incompetente e ineficaz: incompetente porque hace frente a problemas que le son ajenos, de suerte que su intervención carece de legitimidad. E ineficaz por su incapacidad para conducir de forma ordenada las circunstancias generadoras de los peligros que se pretenden evitar con su intervención. Se obliga a insertar en los textos punitivos delitos respecto de los que hay que hacer un esfuerzo dogmático, pero también político-criminal, para identificar un bien jurídico-penal, entendiendo que sólo deberían tener esta consideración aquellos que atañen al contenido esencial de un derecho fundamental.

Así sucede con la Directiva 2009/52/CE del Parlamento Europeo y del Consejo, de 18 de junio de 2009, por la que se establecen normas mínimas sobre las sanciones y medidas aplicables a los empleadores de nacionales de terceros países en situación irregular ${ }^{37}$, y con el art. 311 bis CP español.

Se recurre al Derecho Penal, no con la finalidad de tutelar la vida y salud de las víctimas de la migración ilegal, sino para luchar contra la economía sumergida, en tanto esta afecta a la libre competencia (la dación de empleo sin respetar las condiciones laborales y de Seguridad Social abarata costes); y se recurre a él, por igual, como instrumento de control de los flujos migratorios, es decir, como instrumento de la política de extranjería. Y en la transposición de la norma de la Unión Europea se inserta en el texto punitivo

$\mathrm{n}^{\circ}$ 10, 2008, pp. 1 y ss.; TERRADILLOS BASOCO, J.: «El Derecho penal como estrategia de exclusión: la respuesta punitiva a la inmigración», Revista Penal México, n 3, 2012, pp. 237 y ss.; ZÚÑIGA RODRÍGUEZ, L.: «Trata de seres humanos y criminalidad organizada transnacional: problemas de política criminal desde los derechos humanos», Estudios Penales y Criminológicos, no 38,2018 , pp. 361 y ss.

37 DOUE L 168/24 de 30 de junio de 2009. 
español un precepto innecesario en lo que tiene que ver con la tutela penal de las víctimas de la migración ilegal con fines laborales, pues no cubre ninguna laguna: otros tipos existentes preveían ya esas conductas (art. 311 y $312 \mathrm{CP})^{38}$.

En todo caso, le asiste la razón a Ferrajoli cuando identifica a la legislación italiana en materia de inmigración como un «crimen global» $»^{39}$. Y eso que al momento de salir a la luz su publicación no se conocían los decretos conocidos como decreti Salvini di securezza. En efecto, siendo Ministro del Interior Matteo Salvini, líder de la Liga, partido político populista de corte ultraconservador, promovió dos decretos que permiten afirmar que hoy en Italia se ha criminalizado ayudar a un migrante (sic). Nos referimos al Decreto-Legge 4 ottobre 2018, n. 113. Disposizioni urgenti in materia di protezione internazionale e immigrazione, sicurezza pubblica, nonche' misure per la funzionalita' del Ministero dell'interno e l'organizzazione e il funzionamento dell' Agenzia nazionale per l'amministrazione e la destinazione dei beni sequestrati e confiscati alla criminalita' organizzata (convertido luego en ley, Legge 1 dicembre 2018, n. 132 ${ }^{40}$, y al Decreto-Legge 14 giugno $2019, n$. 53. Disposizioni urgenti in materia di ordine e sicurezza pubblica (convertido en la Legge 8 agosto 2019, $n .77)^{41}$.

38 Vid. NAVARRO CARDOSO, F.: «El delito de contratación ilegal del art. 311 bis CP: un nuevo despropósito, y un viejo vicio, legislativo», en P.M. de la Cuesta Aguado et al. (edits.), Liber Amicorum. Estudios Jurídicos en Homenaje al Prof. Dr. Dr. h.c. Juan $M^{a}$ Terradillos Basoco, Tirant lo Blanch, Valencia, 2018, pp. 1049 y ss. Vid., igualmente, HORTAL IBARRA, J.C.: «Tutela de las condiciones laborales y reformas penales: ¿el ocaso del Derecho Penal del Trabajo?», Revista de Derecho Penal y Criminología, n 20, 2018, pp. 65 y ss.

39 Vid. supra un par de páginas atrás (FERRAJOLI, L.: "Criminología, crímenes globales y Derecho Penal...», cit., p. 7).

40 En línea: https://www.gazzettaufficiale.it/eli/id/2018/10/04/18G00140/ sg. Último acceso: diciembre de 2019.

41 En línea: https://www.gazzettaufficiale.it/eli/id/2019/06/14/19G00063/ sg. Último acceso: diciembre de 2019. 
Este contexto xenófobo "global, internacional y transnacional" ha hecho rebrotar viejas soflamas, algunas de las cuales ya han sido combatidas científicamente, acreditando la falsedad de las mismas. Es el caso, al menos en España, del binomio inmigración-delincuencia, o en términos más recientes, la ominosa introducción de los menores no acompañados en esa ya de por sí falsa ecuación. Se ha tenido ocasión de constatar que era empíricamente indemostrable la concreta imputación pública de aumento de la criminalidad a los migrantes "sin papeles" que se hacía desde medios gubernamentales. Sencillamente, no existía un tratamiento del dato desagregado desde ninguna de las instancias del sistema penal (policial, judicial y penitenciario) que permitiese sostener el binomio inmigración-delincuencia ${ }^{42}$.

Es más, ha sido el tratamiento real y material de la solo teórica libertad de movimiento de las personas el que ha permitido poner en tela de juicio ciertas definiciones de globalización. Tal es así que siempre es de agradecer la introducción de matices que desde ciertas posiciones críticas se hacen. Es el caso de Stiglitz, que define la globalización como "la integración más estrecha de los países y los pueblos del mundo, producida por el enorme reducción de los costes de transporte y comunicación, y el desmantelamiento de las barreras artificiales a los flujos de bienes, servicios, capitales, conocimientos y (en menor grado) personas a través de las fronteras" ${ }^{43}$.

Estrechamente vinculado al tema de los movimientos migratorios aparece el de la aporofobia. Se trata de

42 Vid. NAVARRo CARDOSO, F.: «El Código Penal de la seguridad e inmigración (consideraciones criminológicas y político-criminales)», en M.J. Rodríguez Mesa, L.R. Ruiz Rodríguez (coords.), Inmigración $y$ sistema penal. Retos y desafios para el siglo XXI, Tirant lo Blanch, Valencia, 2006, pp. 223 y ss.; últimamente, GARCÍA ESPAÑA, E.: «Más inmigración, menos delincuencia», Crítica penal y poder, $\mathrm{n}^{\circ} 18$, 2019, pp. 194 y ss.

43 STIGLITZ, J.E.: El malestar en la globalización, cit., p. 30 (la cursiva no está en el original). 
un concepto construido por Cortina Orts en los términos siguientes: "Dícese del odio, repugnancia u hostilidad ante el pobre, el sin recursos, el desamparado"; sugiriendo, en relación con su etiología, "Del gr. Á-poros, pobre, y fóbeo, espantarse" 44 . Casi de modo idéntico lo ha recogido la Real Academia Española de la Lengua en su Diccionario: "Fobia a las personas pobres o desfavorecidas", así como la etiología propuesta y la autoría: "Del gr. ä́opoc áporos 'carente de recursos' y -fobia, término acuñado por la filósofa española A. Cortina" 45 .

Esta nueva perspectiva desde luego que precisa de un análisis empírico en sede penal. La propia Cortina hace una aproximación en relación con los delitos de odio ${ }^{46}$.

En definitiva, puede constatarse que la globalización económica ha tenido una incidencia directa sobre la política criminal. Interesa a partir de ahora profundizar en otras manifestaciones de esa influencia.

\section{Delimitación positiva}

Saliendo de la sede criminológica y adentrándonos en la sede penal, se constata, inmediatamente, esa ya tradicional falta de sintonía entre ambas. Así, Vogel sostiene que claro que la globalización ha incidido en la realidad criminológica, modificándola, pero de forma moderada, y lo que es

44 CORTINA ORTS, A.: Aporofobia, el rechazo al pobre. Un desafio para la democracia, Paidós, Barcelona, 2017, p. 24.

45 REAL ACADEMIA ESPAÑOLA: Diccionario de la lengua española, 23. ${ }^{a}$ ed., 2019 [versión 23.3 en línea: https://dle.rae.es. Ultimo acceso: diciembre de 2019].

46 Ibidem, pp. 29 y ss. Vid., igualmente, BUSTOS RUBIO, M.: Aporofobia y delito. La discriminación socioeconómica como agravante (art. 22.4 ${ }^{a}$ CP), Bosch, Barcelona, 2020; TERRADILlOS BASOCO, J.: «Un sistema penal para la aporofobia», en G. Portilla Contreras, F. Velázquez Velázquez (dirs.), Un juez para la democracia. Libro Homenaje Perfecto Andrés Ibáñez, Dykinson, Madrid, 2019, pp. 353 y ss. 
más relevante, sin que haya tenido lugar lo que en sentido estricto sería una "criminalidad global". Recurre a Prittwitz para advertir que no debería usarse por el simple hecho de que determinados hechos delictivos se cometan en muchos lugares, o en todas partes, pues en ese supuesto el hurto sería el delito global por antonomasia. Y tampoco porque en cualquier fase de comisión del delito (antes, durante o después) se crucen fronteras, lo que tan solo constituiría criminalidad transnacional, pero no necesariamente global ${ }^{47}$.

Tampoco es ese el objeto de atención ahora mismo; es decir, no se trata ahora de saber cuáles deben ser los requisitos o características de un delito para que se le pueda añadir el adjetivo de global. Lo que en este momento nos importa, en orden a definir retos del Derecho Penal global, es la valoración que se hace de ese proceso. Y esa valoración tiene que estar presidida, y no puede ser de otro modo, por la respuesta a una pregunta básica y central: cuánto atacan los procesos globalizadores a los intereses dignos de protección por el Derecho Penal ${ }^{48}$ y, a partir de ahí, si la globalización implica una expansión o un retroceso de la intervención punitiva.

Puede haber una pregunta anterior, que ahora no puede ser atendida, y es si la globalización ha provocado la generación de nuevos bienes jurídicos o, incluso, una nueva categoría, distinta a la de los bienes jurídicos universales, cuyo contenido sea un plus o un aliud respecto de estos.

En todo caso, resulta obvio que en la línea de ataque de conductas que la economía globalizada ha propiciado se encuentran intereses individuales y supraindividuales, lesionados o puestos en peligro. La agresividad de las empresas

47 VOGEL, J.: «Derecho penal y globalización», cit., p. 115; cuestión a la que me referí al inicio del segundo apartado del epígrafe anterior.

48 Coincide en analizar la incidencia de la globalización en el Derecho Penal a partir de su papel esencial como protector de bienes jurídicos, GRACIA MARTÍN, L.: «Criminalidad de la globalización y Derecho penal», cit., pp. 24 y 25. 
transnacionales por elevar sus beneficios ha provocado, como hemos visto, además de conductas corruptas (dando lugar a la internacionalización de la corrupción $)^{49}$, a comportamientos lesivos de intereses de toda índole, como son los derechos de los trabajadores o el medio ambiente. Es el tributo por el ahorro de costes para maximizar el beneficio (sin que tampoco sea ajeno el incremento de costes producto de la corrupción). Al mismo tiempo, el desarrollo tecnológico ha traído una globalización tecnológica que parece que sí que ha propiciado la aparición de nuevos derechos humanos, incluso, de una nueva generación de derechos humanos ${ }^{50}$.

Pues bien, en relación al nivel de incidencia, se constatan dos visiones antagónicas ${ }^{51}$, que pueden personalizarse en las posiciones de Silva Sánchez y Terradillos Basoco. Silva sostiene que la globalización tiene un efecto multiplicador, es decir, que incrementa la expansión del Derecho Penal; lo que no es óbice para que lo critique ${ }^{52}$. Terradillos, por el contrario, entiende que la globalización es un factor desincentivador del Derecho Penal, pues aquella provoca la desregulación de los mercados y de las políticas, generando un desplazamiento del Derecho Penal; lo que también critica ${ }^{53}$.

49 Vid., últimamente, BERDUGO GÓMEZ DE LA TORRE, I.: «El soborno internacional: normas, obstáculos y propuestas», cit., 166 a 168.

50 Vid., por todos, PÉREZ LUÑO, A.E.: «Las generaciones de derechos humanos», en F. J. Ansuátegui Roig, J. Rodríguez Uribes, G. PecesBarba, E. Fernández García, Historia de los derechos fundamentales, vol. 4, t. I, Dykinson, Madrid, 1998, pp. 359 y ss. Sobre una nueva generación de derechos humanos, BUSTAMANTE DONAS, J.: «La cuarta generación de derechos humanos en las redes digitales: segundos pensamientos», Telos: Cuadernos de comunicación e innovación, $\mathrm{n}^{\circ}$ 85, 2010, pp. 80 y ss., y la bibliografía ahí citada [En línea: https://telos.fundaciontelefonica.com. Ultimo acceso: diciembre de 2019].

51 VOGEL, J.: «Derecho penal y globalización», cit., p. 113.

52 SILVA SÁNCHEZ, J.M.: La expansión del Derecho penal. Aspectos de la politica criminal en las sociedades posindustriales, $2^{\mathrm{a}}$ edic., Civitas, Madrid, 2001, pp. 81 y ss. (hay una $3^{\text {a }}$ edic., Edisofer, Buenos Aires, 2011).

53 TERRADILLOS BASOCO, J.: «Globalización, administrativización y expansión del Derecho penal económico», Nuevo Foro Penal, $\mathrm{n}^{\circ} 70$, 2006, pp. 86 y ss., 91 y ss. 
Vogel opina, al contrario que Ferrajoli, que la «criminalidad de la globalización» no tiene que coincidir necesariamente con la «criminalidad global». Es más, sostiene que aunque se trate de una "criminalidad organizada de los poderosos, aún habría que fundamentar por qué los poderosos han de ser peores personas que los impotentes cuando actúan de modo criminal y por qué debe considerarse la criminalidad organizada transnacional especialmente peligrosa y nociva" 54 .

Más allá de la mirada tal vez un tanto cándida de este último autor, no por la primera parte de su afirmación, sino por la segunda - dicho sea con todo afecto y sincera admiración hacia el fallecido colega alemán-, opino que le asiste la razón a Terradillos, y me sirve para poner de manifiesto las cuestiones centrales de mis reflexiones en torno a los retos del Derecho Penal global.

\section{Los compromisos supranacionales públicos y privados}

Consustancial a los procesos globalizadores es la necesidad de generar compromisos que superen el espacio local y atiendan a las necesidades globales. De modo harto sintético, intrínsecos a la globalización son los compromisos internacionales (públicos y privados, como veremos), pues aquella se ha venido caracterizando, como ya dijimos más arriba, por ser un período de interacción, interrelación e interdependencia mundiales. Podría corresponderse con el llamado Global Law, pero tampoco quiero entretenerme en esta discutida categoría ${ }^{55}$.

54 VOGEL, J.: «Derecho penal y globalización», cit., p. 117.

55 Vid., negándola, IGLESIAS VÁZQUEZ, M.A.: «Globalización, globalización jurídica, Global Law y Derecho Internacional Privado», Cuadernos de Derecho Transnacional, vol. 9, n 1, 2017, pp. 215 y ss. Para esta autora, el Global Law es, en definitiva, el Derecho Internacional Público, el cual no ha fracasado, y por tanto, no anda necesitado de 
Una de las características en el ámbito jurídico de este proceso es la clara influencia del pensamiento problemático, de suerte que la solución normativa está orientada a dar respuesta a concretos problemas prácticos. Una de sus consecuencias en sede jurídico-penal es que el producto propio del pensamiento sistemático, las cuestiones dogmáticas, son más o menos relegadas, pues lo relevante es el problema y su solución ${ }^{56}$. En definitiva, prevalece un discurso pragmático frente a un posible previo debate categorial.

Otra de las características es que estas regulaciones pueden contener mandatos sancionadores, como así ha venido sucediendo con muchos compromisos internacionales orientados a la lucha contra la delincuencia producto de la globalización. El inconveniente surge porque, en ocasiones, se llega a afirmar que dichos compromisos demandan una respuesta concretamente punitiva, justificándose así una

ningún remedo o alternativa (p. 234).Vid., igualmente, FISCHERLESCANO, A.; GUNTHER TEUBNER, G.: «Regime-Collisions: The Vain Search for Legal Unity in the Fragmentation of Global Law», Michigan Journal of International Law, vol. 25, 2004, pp. 999 y ss. Parten de la existencia de un Derecho Global, si bien constatan la existencia de una fragmentación, producto no de tensiones estrictamente jurídicas (de convivencia de modelos), sino de tensiones "políticas". Lo explican del modo siguiente: "En esta perspectiva política, las colisiones entre normas jurídicas no son más que un espejo de las estrategias seguidas por nuevos actores colectivos dentro de las relaciones internacionales, que persiguen «intereses especiales» impulsados por el poder, sin hacer referencia a un interés común, y dan lugar a drásticos "conflictos políticos»". Vid., in extenso, DOMINGO OSLÉ, R.: ¿Qué es el Derecho Global?, Consejo General del Poder Judicial, Madrid, 2007 (hay una $2^{\mathrm{a}}$ edic., Aranzadi, Cizur Menor, 2008).

56 Vid. AMBOS, K.: «Zur Zukunft der deutschen Strafrechtswissenschaft: Offenheit und diskursive Methodik statt selbstbewusster Provinzialität», en K. Tiedemman et al. (edits.), Die Verfassung moderner Strafrechtspflege. Erinnerung an Joachim Vogel, Nomos, Baden-Baden, 2016, pp. 321 y ss., p. 324; PERRON, W.: «Europäische und transnationale Strafrechtspflege als Herausforderung für eine modern Strafrechtdogmatik», en K. Tiedemman et al. (edits.), Die Verfassung moderner Strafrechtspflege..., cit., pp. 307 y ss., 316. 
modificación del Código Penal. En realidad, tal aseveración es, reitero, en ocasiones, solo producto de una lectura sesgada de esas exigencias.

Un ejemplo paradigmático en este punto puede ser la tipificación de la modalidad imprudente del blanqueo de capitales. Salvo error u omisión, no hay ningún compromiso internacional ni regional que exija expresamente tal previsión normativa. El Convenio de Estrasburgo sobre el blanqueo de 1990 mandata que se castigue el blanqueo doloso (art. 6.1), y solo sugiere que se castigue la modalidad imprudente. Los términos de la redacción son indubitados: recurre al verbo "podrá" ("Cada Parte podrá adoptar las medidas que considere necesarias para tipificar también como delitos") en los casos en los que "el delincuente debería haber presumido que los bienes eran producto de un delito" [art. 6.3 a)]. Y en los mismos términos se pronuncia el Convenio de Varsovia de 2005 relativo al blanqueo, en este caso, en los art. 9.1 respecto al blanqueo doloso y 9.3 b) respecto al imprudente ${ }^{57}$.

No obstante lo anterior, países como España lo prevén (art. 301.3 CP), y se justifica en atención a obligaciones de origen convencional contraídas por España, lo que es incierto. A ello se suma que, en estrictos términos dogmáticos, dada la redacción de los preceptos (como el citado art. $301 \mathrm{CP}$ español, inspirados en las convenciones citadas), se están castigando participaciones y actos preparatorios, imprudentes; lo que no ha sido objeto de debate, precisamente, porque las cuestiones dogmáticas resultan relegadas.

57 Instrumento de Ratificación por parte de España del Convenio relativo al blanqueo, seguimiento, embargo y decomiso de los productos del delito, hecho en Estrasburgo el 8 de noviembre de 1990 (BOE ${ }^{\circ}$ 252, de 21 de octubre de 1998), e Instrumento de Ratificación por parte de España del Convenio relativo al blanqueo, seguimiento, embargo y comiso de los productos del delito y a la financiación del terrorismo, hecho en Varsovia el 16 de mayo de 2005 (BOE n ${ }^{\circ} 155$, de 26 de junio de 2010). 
Sin ir más lejos, la distinción entre autoría y participación, o entre preparación y ejecución del delito.

También lo es, en parte, la responsabilidad penal de las personas jurídicas. Tomando la referencia española, dice el apartado VII del Preámbulo de la Ley Orgánica 5/2010, de 22 de junio, por la que se modifica la Ley Orgánica 10/1995, de 23 de noviembre, del Código Penal ${ }^{58}$, que "son numerosos los instrumentos jurídicos internacionales que demandan una respuesta penal clara para las personas jurídicas". Obviamente, debe pensarse en compromisos internacionales asumidos por España. Pues bien, ni eran tan numerosos ni demandaban un régimen general de responsabilidad penal de las personas jurídicas. Cierto que existía, por ejemplo, la ya citada Directiva 2009/52/CE del Parlamento Europeo y del Consejo de 18 de junio de 2009, por la que se establecen normas mínimas sobre las sanciones y medidas aplicables a los empleadores de nacionales de terceros países en situación irregular. Sus artículos 11 y 12 la fijan. Pero el celo cumplidor del legislador queda muy en entredicho cuando el motivo principal por el que se mandata esta previsión no es satisfecho, sin embargo, hasta el año 2015, momento en el que se introduce el art. 311 bis $\mathrm{CP}^{59}$.

En otras ocasiones no se impone expresamente que la respuesta a un problema deba provenir del Derecho Penal. Se exige, en todo caso, que se trate de "sanciones efectivas, proporcionadas y disuasorias", expresión ya clásica en el Derecho de la Unión Europea ${ }^{60}$. Pero lo cierto es que,

58 BOE n $^{\circ} 152$, de 23 de junio.

59 Vid. NAVARRO CARDOSO, F.: «El delito de contratación ilegal del art. 311 bis CP: un nuevo despropósito, y un viejo vicio, legislativo», cit., pp. 1049 a 1052 .

60 Es la contenida, por ejemplo, en la conocida como Quinta Directiva antiblanqueo, la Directiva (UE) 2018/843 del Parlamento Europeo y del Consejo de 30 de mayo de 2018 por la que se modifica la Directiva (UE) 2015/849 relativa a la Prevención de la Utilización del Sistema Financiero para el Blanqueo de Capitales o la Financiación del Terrorismo, y por 
producto de esa lectura sesgada a la que se acaba de aludir, la respuesta termina siendo de naturaleza penal.

Este fervor punitivista lo puede explicar la Teoría Política como una manifestación de populismo punitivo, entendido como el recurso al Derecho Penal para la gestión de los problemas sociales, y materialización de una muy determinada política criminal, dominante durante los últimos períodos de la globalización: la propia del neoliberalismo.

En síntesis, para un sector de la doctrina, estos efectos perversos de la globalización son un genuino producto neoliberal (y neoconservador), que han provocado un recurso insoportable al populismo punitivo. Desde este se transmite la impresión de que castigando más se resuelve o, cuando menos, se palia el problema.

De lo dicho se constata que he dejado al margen los procesos estrictos de «armonización penal». Se entiende por tales aquellos que tienden a reforzar la justicia y la eficacia de la respuesta penal en temas concretos a través de formas de acercamiento de los distintos modelos y sistemas en contextos regionales, y que, respetuosos con las idiosincrasias nacionales, permiten ciertos márgenes de concreción. Estos procesos, de hecho, son considerados como un valor a perseguir, recibiendo, pues, una valoración positiva ${ }^{61}$.

la que se modifican las Directivas 2009/138/CE y 2013/36/UE (DOUE L 156, de 19 de septiembre de 2018).

61 BERNARDI, A.: «El Derecho Penal entre la globalización y multiculturalismo», Revista de Derecho y Proceso Penal, nº 8, 2002, pp. 13 y ss., 17 y ss. En igual sentido, SILVA SÁNCHEZ, J.M.: La expansión del Derecho Penal..., cit., pp. 88 y 89, en tanto sostiene que un Derecho Penal armonizado como materialización del Derecho Penal de la globalización es mucho más que el Derecho producto de las armonizaciones penales, en tanto debe alcanzar a todo el sistema penal. Debe incluir, pues, no solo una Parte Especial homogeneizada, sino también una Parte General con igual característica, que englobe a las garantías y principios político-criminales. 
Del mismo modo, también he dejado al margen el nuevo orden penal internacional sintetizado en la rúbrica «internacionalización del Derecho Penal», donde el Estatuto de Roma y su Tribunal Penal Internacional son un excelente ejemplo. Se trata de compromisos internacionales promovidos en defensa y fomento de los derechos humanos, lo que merece una valoración positiva ${ }^{62}$.

Otra muy relevante característica de los compromisos internacionales producto de la globalización es que, como pone de manifiesto acertadamente González Cussac, a menudo tienen su origen en organismos internacionales privados, de un complejo entramado de actores no públicos de la escena internacional ${ }^{63}$; carentes, pues, de legitimidad parlamentaria en origen, lo que permite hablar de déficit democrático. Capella Hernández se refiere a ellos de modo harto elocuente como "soberano privado supraestatal difuso"64; expresión que acoge Terradillos Basoco ${ }^{65}$.

Aun cuando la trasposición de estas orientaciones o decisiones es competencia de los parlamentos nacionales, no es menos cierto que en la práctica vienen compelidos a adop$\operatorname{tarlas}^{66}$.

62 Vid. BERNARDI, A.: «El Derecho Penal entre la globalización y multiculturalismo», cit.; BORJA JIMÉNEZ, E.: «Globalización y concepciones del Derecho Penal», Estudios Penales y Criminológicos, t. XXIX, 2009, pp. 141 y ss. Coincidente con esta exclusión, GRACIA MARTÍN, L.: "Criminalidad de la globalización y Derecho penal», cit., p. 39.

63 GONZÁlEZ CUSSAC, J.L.: «El plano político criminal en la responsabilidad penal de las personas jurídicas», en A. Matallín Evangelio (dir.), Compliance y prevención de delitos de corrupción, Tirant lo Blanch, Valencia, 2018, pp. 95 y 96.

64 CAPELLA HERNÁNDEZ, J.R.: «Estado y derecho ante la mundialización: aspectos y problemáticas generales», cit., p. 106. Vid., el mismo, Fruta prohibida. Una aproximación histórico-teorética al estudio del derecho y del estado, Trotta, Madrid, 1997 (hay una $6^{\text {a }}$ edic., 2008).

65 TERRADILLOS BASOCO, J.: «Globalización, administrativización y expansión del Derecho penal económico», cit., p. 93.

66 Vid. CAPELLA HERNÁNDEZ, J.R.: «Estado y derecho ante la mundialización: aspectos y problemáticas generales», cit., pp. 85 y ss.; 
Obsérvese que lo más relevante aquí no es que sean actores no estatales que participan en la creación de Derecho en general, sino de Derecho sancionador, cuando no directamente de Derecho Penal. Y tampoco que sean supraestatales, como sucede con la Unión Europea, sino, en definitiva, de actores privados que generan compromisos o reglas internacionales (soft law) que inciden, de modo más o menos directo, en la legislación penal.

Es de obligada cita en este punto el GAFI, Grupo de Acción Financiera Internacional, que en materia de blanqueo de capitales, financiación del terrorismo y otras actividades delictivas contra la integridad del sistema financiero, viene demandando medidas sancionadoras concretas a través de sus recomendaciones. Un análisis de alguna de estas "propuestas" (entre comillas) permite advertir rápidamente que se trata de incumplimientos administrativos de obligaciones, como por ejemplo, la obligación de comunicar una operación sospechosa en el ámbito del blanqueo de dinero. Se trata, en concreto, del incumplimiento imprudente de una obligación de comunicar una operación que puede entrañar un potencial peligro de blanqueo o de financiación del terrorismo. En este caso, el legislador español ha optado por calificarla de delito: art. 576.4 CP. Pero no puede, ni debe pasar inadvertido para un penalista que, en estrictos términos dogmáticos, representa el castigo de un acto preparatorio imprudente ${ }^{67}$.

Claro que puede afirmarse que se trata técnicamente de recomendaciones, y que, por lo tanto, no son fuente crea-

NIETO MARTÍN, A.: «Derecho penal y Constitución en la era del Global Law», en S. Mir Puig, M. Corcoy Bidasolo (dirs.), Garantías constitucionales y Derecho penal europeo, Marcial Pons, Madrid, 2012, pp. 83 y ss., 89 .

67 Sobre este tipo penal, vid. FERRÉ OLIVÉ, J.C.: «Instrumentos internacionales en la lucha contra la financiación del terrorismo», en J.C. Ferré Olivé, A.I. Pérez Cepeda (dirs.), Financiación del terrorismo, Tirant lo Blanch, Valencia, 2018, pp. 57 y ss., 76 y ss. 
dora de Derecho: "La presión es presión pero no es poder normativo como tal" 68 . Tal vez este razonamiento sea sostenible respecto de determinadas áreas normativas. Pero no puede pasar desapercibido, primero, que aun dentro de las áreas geográficas donde rige el principio de legalidad penal, las matizaciones son cada vez más intensas, al punto de poder convivir, armoniosamente, con el principio de oportunidad (como sucede en España entre la responsabilidad penal de los adultos y la de los menores). Segundo, tampoco puede pasar por alto que materialmente se está dotando de contenido a ciertas categorías en sede penal, como sucede con conceptos ya aquilatados como el de administrador de hecho, o el de autor mediato, sobre todo cuando se trata de la imputación personal en el ámbito de estructuras organizadas de poder. Y tercero, a nadie se le escapa, dicho en términos coloquiales, que más le vale a cada país seguir las recomendaciones del GAFI, no vaya a ser que luego pueda tener problemas para acceder a la financiación del Fondo Monetario Internacional y del Banco Mundial. Es por ello por lo que antes me referí a sus recomendaciones como propuestas entrecomillando la palabra. En definitiva, soft law solo en términos formales.

\section{La desregulación y la autorregulación regulada}

En opinión de algunos, la llamada «desregulación» es otro genuino producto neoliberal que se expande con la globalización. Como dice Terradillos Basoco, "la desregulación, compañera inseparable de la globalización" $"$.

68 IGLESIAS VÁZQUEZ, M.A.: «Globalización, globalización jurídica, Global Law y Derecho Internacional Privado», cit., p. 219.

69 TERRADILLOS BASOCO, J.: «Globalización, administrativización y expansión del Derecho penal económico», cit., p. 95. Vinculan también globalización y desregulación, entre otros, NIETO, A.: Una introducción al derecho, Tirant lo Blanch, Valencia, 2019, p. 68; SILVA SÁNCHEZ, J.M.: La expansión del Derecho penal..., cit., p. 136. 
Técnicamente no se trata de una ausencia de regulación, sino un peculiar modo de producción normativa. Se caracteriza por el desplazamiento de la exclusiva fuente pública de generación de la norma en favor de la autonomía privada, concretada en grupos de interés económico o social, frente a los que el Estado retrocede en su actividad legiferante ${ }^{70}$.

Capella Hernández vincula directamente desregulación y globalización (mundialización, en expresión preferida por este filósofo del Derecho, tal como ya apuntamos ${ }^{71}$ ), donde el poder "político" ha modificado su estructura con la aparición de un "soberano privado supraestatal difuso" -expresión a la que ya antes aludimos-, interrelacionado en un "campo de poder" con los estados ${ }^{72}$. Uno de los cambios relevantes, en lo que aquí interesa, es que "donde antes el Estado velaba por el cumplimiento de los deberes impuestos al empresariado vela ahora por los privilegios concedidos a éste"

En este marco hay que situar la llamada «autorregulación regulada». Para un sector de la doctrina administrativista, que se ha ocupado bastante de este tema, en este caso no se produce ese retraimiento del Estado. No es así debido a que no implica un adelgazamiento de las funciones estatales, sino que los poderes públicos toleran, en aras de la eficacia y de la eficiencia, normas producidas en el ámbito privado, que las hacen suyas, aunque provengan de lo privado, porque están orientadas a la satisfacción del interés general.

70 Vid. MARCILlA CÓRDOBA, G.: «Desregulación, Estado social y proceso de globalización», Doxa, Cuadernos de Filosofía del Derecho, $\mathrm{n}^{\mathrm{o}}$ 28, 2005, pp. 239 y ss.

71 CAPELLA HERNÁNDEZ, J.R.: «Estado y derecho ante la mundialización: aspectos y problemáticas generales», cit., p. 85.

72 Ibidem, pp. 106 y ss. Vid., también, SAMPEDRO, J.L.: El mercado y la globalización, Destino, Barcelona, 2002, pp. 65 y ss.

73 CAPELLA HERNÁNDEZ, J.R.: «Estado y derecho ante la mundialización: aspectos y problemáticas generales», cit., p. 109. Coinciden, pues, entre otros, este autor y Gracia Martín (vid. supra nota 24). 
Para otro sector doctrinal, como puede resultar obvio, ello enmascara una nueva conquista neoliberal, con un muy importante matiz: una nueva conquista muy alarmante en tanto alcanza al sistema sancionador, es decir, a la fijación de infracciones y sanciones ${ }^{74}$. Dicho de otro modo, el Estado cede páginas en blanco del ius puniendi para que desde lo privado se rellenen.

¿Cómo opera? Puede explicarse de modo bien sencillo: el Estado, en una determinada materia, fija el marco regulatorio, y cede a los entes privados la concreción normativa vía códigos internos, reservándose, en algunos casos, la capacidad sancionadora.

Las razones para este modo de proceder, se aduce, son: la complejidad técnica de la materia; la búsqueda de la eficacia y la eficiencia; así como la incapacidad del Estado para producir con solvencia, conforme a esos criterios, la regulación que precisa la moderna y sofisticada actividad empresarial.

Es en este marco en el que hay que situar a los programas de cumplimiento normativo, conocidos como compliance programs, tan en boga hoy en el Derecho Penal por mor de la introducción en muchos ordenamientos de la responsabilidad penal de las personas jurídicas, y que, como bien advierte Ferré Olivé, tanta perplejidad comienzan a causar ${ }^{75}$.

74 MARCILLA CÓRDOBA, G.: «Desregulación, Estado social y proceso de globalización», cit., pp. 247 y ss., 252, y la bibliografía ahí citada.

75 Formula unas agudas reflexiones sobre la autorregulación regulada y compliance FERRÉ OLIVÉ, J.C.: «Reflexiones en torno al compliance penal y la ética en la empresa», Revista Penal, nº 44, 2019, pp. 61 y ss. De la narrativa del compliance da cumplida cuenta, por ejemplo, respecto al acotamiento del constructo "cultura de cumplimiento", ORTIZ DE URBINA GIMENO, I.: "Cultura de cumplimiento y exención de responsabilidad de las personas jurídicas», Revista Internacional de Transparencia e Integridad, $\mathrm{n}^{\circ}$ 6, 2018 [En línea: https://revistainternacionaltransparencia.org/wp-content/uploads/2018/04/iñigo ortiz.pdf. Último acceso: mayo de 2018]. 
¿Qué matiz diferencia esta cuestión en concreto de la desregulación en general? Pues que, en parte, aquí se busca, indirecta e inconfesadamente, no la regulación indirecta, sino la exoneración indirecta de responsabilidad ${ }^{76}$.

Recurro a la responsabilidad penal de las personas jurídicas por paradigmático. Traerla al Derecho Penal supone, de entrada, que ya no hay respuesta administrativosancionadora. Se neutraliza, pues, la reacción que pueda provenir desde las administraciones públicas en forma de sanción administrativa. Se explica, obviamente, en razón de salvaguarda de la prohibición de doble sanción; es decir, para no transgredir el principio non bis in idem.

Pero se inserta en el Derecho Penal acompañada de un régimen de exención, de discutida naturaleza penal ${ }^{77}$ (o aceptada su naturaleza penal, discutida su naturaleza dogmática de elemento excluyente del injusto, de la culpabilidad o de la punibilidad), de modo que al final podemos asistir a un

76 Ello en consonancia con la perspectiva económico-financiera de la desregulación económica que promueve la globalización neoliberal (distinta de la perspectiva holística que manejan algunos en la Sociología, caso de GUIDDENS, A.: Consecuencias de la modernidad, Alianza, Madrid, 2004). Vid. ANTÓN-MELlÓN, J.; ÁlVAREZ, G.; ROTHSTEIN, P. E.: «Populismo punitivo en España (1995-2015): presión mediática y reformas legislativas», Revista Española de Ciencia Política, ${ }^{\circ}$ 43, 2017, p. 7. Coincidente con el texto, GONZÁLEZ CUSSAC, J.L.: «El plano político criminal en la responsabilidad penal de las personas jurídicas», cit., pp. 100 y ss. Sobre la ideología de la expansión del Derecho Penal económico, vid. también DEMETRIO CRESPO, E.: «El significado político del Derecho Penal económico», en E. Demetrio Crespo (dir.), Crisis financiera y Derecho Penal Económico, B de F, Buenos Aires, 2014, pp. 3 y ss.

77 Vid. LEÓN ALAPONT, J.: «Criminal compliance: análisis de los arts. 31 bis 2 a 5 CP y 31 quater CP», Revista General de Derecho Penal, $\mathrm{n}^{\circ} 31$, 2019, defendiendo que el programa de cumplimiento sí tiene naturaleza penal y que, por ende, su régimen debe estar inserto en el Código Penal (p. 35). Vid., de igual modo, GONZÁLEZ CUSSAC, J.L.: «La eficacia eximente de los programas de prevención de delitos», Estudios Penales y Criminológicos, vol. XXXIX, 2019, pp. 593 y ss. 
increíble ejercicio de «gatopardismo»: "Si queremos que todo siga como está, necesitamos que todo cambie".

En definitiva, la empresa no responde, ni administrativa ni penalmente. Con respecto a esto todavía no se ha explicado todavía suficientemente por qué hay que desdeñar la respuesta administrativo-sancionadora y optar por la penal $^{78}$; y más cuando la exoneración viene vía autorregulación, lo cual no deja de resultar paradójico. No deja de ser una tremenda incongruencia lógica que uno de los principales argumentos empleados sea el fracaso de la autorregulación de las empresas, y luego se acuda precisamente a ella para exonerar a esa persona jurídica de su responsabilidad.

En efecto. Uno de los fundamentos político-criminales de la promoción de la responsabilidad penal de las personas jurídicas es el fracaso de la apuesta por la autorregulación; es decir, por dejar que fuese la propia empresa la que estableciese sus normas internas que le permitiesen el desarrollo de su actividad económica sin vulnerar el ordenamiento jurídico. Sorprende, y mucho, porque el modelo de imputación penal a la empresa lleva implícito, por razones de lógica intrasistemática, pero también extrasistemática,

78 En este punto es de obligada cita los trabajos de Gracia Martín. Vid., últimamente, GRACIA MARTÍN, L.: «Crítica de las modernas construcciones de una mal llamada responsabilidad penal de la persona jurídica», Revista Electrónica de Ciencia Penal y Criminología, nº 18, 2016, pp. 1 y ss.

El argumento de la ineficacia de la respuesta sancionadora administrativa transmite, en ocasiones (y dependiendo, claro está, del contexto en que es esgrimido), una impresión ciertamente paradójica, dicho sea en el sentido más literal de la palabra, pues fácilmente cualquiera puede preguntarse, a renglón seguido, si es que no se mata, no se roba, o no se viola, y mucho.

En todo caso, se me antoja indubitado que los arts. 31 bis y siguientes del Código Penal español consagran un régimen penal de responsabilidad para la persona jurídica. Vid., últimamente, GALÁN MUÑOZ, A.: Fundamentos y límites de la responsabilidad penal de las personas jurídicas tras la reforma de la LO 1/2015, Tirant lo Blanch, Valencia, 2017; fundamentalmente, en lo que a esta cuestión se refiere, pp. 67 y ss. 
la antes citada previsión de exención de responsabilidad, basada en la autoorganización, esto es, en la implementación de una cultura de cumplimiento, que se materializa, entre otros extremos, en unos programas de cumplimiento normativo que ella misma se impone.

Mutatis mutandi, podría traerse aquí la opinión de Prittwitz acerca del resultado del debate sobre el rendimiento material del Derecho Penal frente a los riesgos sistémicos. Es de sobra conocida su posición contraria a la intervención del Derecho Penal respecto de ellos ${ }^{79}$. Sin embargo, cree que ha vencido la posición contraria. Y ello debido a una alianza entre aquellos que esperan un papel que él opina que es de imposible cumplimiento por parte del Derecho Penal, "y aquellos otros que, claramente, son los beneficiarios del (mal) uso del Derecho Penal", refiriéndose, en el contexto del medio ambiente, a las industrias dañosas ${ }^{80}$.

En definitiva, expresado seguramente de modo muy grueso, no es que se haya generado un espacio para autorregularse (en parte consustancial al Estado liberal de Derecho), sino para autoexcluirse penalmente.

79 Vid. PRITTWITZ, C.: Strafrecht und Risiko. Untersuchungen zur Krise von Strafrecht und Kriminalpolitik in der Risikogesellschaft, Klostermann, Frankfurt am Main, 1993. Un resumen en español en, el mismo, «Sociedad del riesgo y Derecho penal», en L. Arroyo Zapatero, A. Nieto Martín, U. Neumann (coords.), Crítica y justificación del derecho penal en el cambio de siglo: el análisis crítico de la Escuela de Frankfurt, Ediciones de la Universidad de Castilla-La Mancha, Cuenca, 2003, pp. 259 y ss.

80 PRITTWITZ, C.: «La función del Derecho Penal en la sociedad globalizada del riesgo: defensa de un rol necesariamente modesto», en E. Pérez Alonso et al. (edits.), Derecho, globalización, riesgo y medio ambiente, Tirant lo Blanch, Valencia, 2012, p. 425. 


\section{Algunos productos dogmáticos}

La globalización no solo ha incidido en la Política Criminal. También ha generado cambios en la Dogmática ${ }^{81}$. A algunos de ellos quiero referirme ahora, y de modo breve.

El primero, que, al menos en su formulación teórica, puede recibir una valoración positiva es el acercamiento entre las legislaciones penales al acoger soluciones comunes. Cierto que en realidad se trata, sobre todo, de la influencia de un sistema dogmático, el alemán, en otras latitudes, pero en tanto existen problemas comunes (comisión por omisión, legítima defensa, estado de necesidad, etc.). En muchos casos son una suerte de expansión cultural, favorablemente acogida, con sus correspondientes adaptaciones, al menos en ocasiones. Son, pues, procesos más o menos simétricos de creación de la norma (España es un buen ejemplo). En otros, sin embargo, más que una expansión, tal vez sería más preciso hablar de una invasión, pues aquel modelo fue replicado sin más, sin tener presente peculiaridad local alguna. Estos casos son claramente procesos asimétricos de importación normativa (Paraguay es un buen ejemplo) ${ }^{82}$.

Otro cambio es la progresiva comunión entre los dos grandes modelos existentes hoy, el common law y el civil law, $\mathrm{y}$ en lo que ahora me interesa, el progresivo espacio que va ocupando el principio de legalidad y el principio de oportunidad en cada uno de ellos, respectivamente hablando. Las fórmulas de «justicia colaborativa» que están implementándose, en unos casos, o desarrollándose, en otros, están conformando una nueva dogmática, no solo sustantiva (que también, con incidencia en los juicios de tipicidad y culpabi-

81 Aquí también serían inabarcables las referencias bibliográficas. Vid. una buena aproximación en BORJA JIMÉNEZ, E.: "Globalización y concepciones del Derecho Penal», cit., pp. 141 y ss.

82 Vid. algunas reflexiones al respecto en BORJA JIMÉNEZ, E.: «Globalización y concepciones del Derecho Penal», cit., pp. 164 y ss. 
lidad), sino también procesal. Creo que la delación premiada o la sentencia de conformidad son claros ejemplos ${ }^{83}$.

Este otro cambio ha incidido en el proceso anterior, minimizando en parte sus efectos. Así, la influencia de la dogmática jurídico-penal alemana (y, por ende, la impronta dejada) puede entenderse que ha disminuido a favor de teorías y soluciones pensadas en el contexto del Common Law, producto del proceso de internacionalización del Derecho Penal.

Y otro cambio tiene que ver con la ecuación «globalización-sociedad del riesgo-peligro y peligrosidad $»^{84}$.

Como dice Prittwitz, el vínculo entre la globalización y el peligro es el riesgo ${ }^{85}$. En este contexto, por nadie se discute que se ha estado produciendo un cambio de paradigma, y es la anticipación como estrategia para la dación de seguridad. Traído a nuestro ámbito, el criterio de selección normativa ya no es el peligro sino la peligrosidad. Ello requiere, puede que no tanto un nuevo relato de las garantías y de las reglas de imputación (aunque propuestas en este sentido hay), pero sí un relajamiento (en ocasiones, abrupto) de las mismas.

De entrada, las referencias a la seguridad abren un abanico tan extenso como peligroso. Sobre todo, porque se

83 Vid. FERRÉ OLIVÉ, J.C.: «El Plea Bargaining, o cómo pervertir la justicia penal a través de un sistema de conformidades low cost», Revista Electrónica de Ciencia Penal y Criminología, nº 20, 2018.

84 Una ecuación que debiera conducir aquí a una nueva disgregación -lo que no va a suceder- sobre las más modernas explicaciones acerca de las incertidumbres (alejadas del constructo «sociedad del riesgo»), las cuales atenazan a la propia reflexión científica, como el propio Beck explicita en su discurso laudatorio a Z. Bauman ante la Sociedad Alemana de Sociología, y donde Beck, por cierto, vuelve a hacer referencia a la «sociedad del riesgo». Beck, U.: «Un voto a favor del regreso de la historia social», Diario El Clarín, 12 de enero de 2015 [en línea: https://www.clarin.com. Último acceso: agosto de 2020].

85 PRITTWITZ, C.: «La función del Derecho Penal en la sociedad globalizada del riesgo:...», cit., p. 416, aunque se refiere, en un principio, al peligro medioambiental. 
recurre a un concepto vago de aquella, carente de las precisiones y matizaciones que demanda en cada contexto, de las que el lenguaje político, en general, y la política criminal, en particular, se desentienden en demasiadas ocasiones. Como dije hace tiempo, esta instrumentalización de la idea de seguridad desemboca en el ejercicio de actuaciones políticas y legislativas disparatadas, en tanto carentes de una fundamentación sólida y particularizada: la simple idea de seguridad sirve para justificar tanto decisiones de política criminal en el ámbito de la violencia de género como decisiones de política de defensa en materia de misiles balísticos que transportan armas de destrucción masiva. Siendo los dos temas de indudable relevancia, parece evidente que la dación de seguridad a las víctimas de la violencia de género precisa de unas políticas concretas bien diferentes a la dación de seguridad a la población víctima de las armas de destrucción masiva. Y en el debate político, en ocasiones excesivamente simplista, se reducen al mínimo los matices, cuando no se hacen desaparecer ${ }^{86}$.

$\mathrm{Si}$ a ello se une que en ciertos ámbitos ya no se gestiona la seguridad sino la incertidumbre, el resultado en términos normativos se visualiza en la agudización del tránsito del peligro a la peligrosidad, del hecho al pronóstico, con el incremento en la relajación de las garantías y reglas de imputación.

Una aclaración. No estoy refiriéndome desde luego al «Derecho Penal de la peligrosidad» vinculado a la culpabilidad del sujeto, y a la correlativa imposición de medidas de seguridad en el ámbito de la delincuencia sexual, por ejemplo $^{87}$. El Derecho Penal, en todo caso, ya tiene experiencia en

86 NAVARRO CARDOSO, F.: «El Derecho penal del riesgo y la idea de seguridad. Una quiebra del sistema sancionador», en F. Pérez Álvarez (ed.), Serta. In Memoriam Alexandri Baratta, Servicio de Publicaciones de la Universidad de Salamanca, Salamanca, 2004, pp. 1321 y ss., 1338 y 1339 .

87 Vid., últimamente sobre el tema, REBOLLO VARGAS, R.: «A vueltas con el Derecho penal de la peligrosidad» en De la Cuesta Aguado, 
la gestión de la incertidumbre. Me refiero a la incertidumbre científica que condujo a la incorporación del principio de precaución desde el Derecho de la Unión Europea (que, a su vez, lo incorpora del Derecho Administrativo alemán) para la gestión del riesgo permitido, por ejemplo, en el ámbito de la salud pública ${ }^{88}$.

González Cussac vincula la gestión de la incertidumbre a los servicios de inteligencia, teniendo en cuenta que "la inteligencia no opera en el ámbito trazado por la descripción de hechos delictivos, sino en la esfera de situaciones en todo caso "pre-delictuales», es decir, que todavía no son delictivos y quizá nunca lo sean, pero ex ante, ahora, constituyen riesgos potenciales para la seguridad"89.

Tomo la idea, no desde la perspectiva político-criminal desde la que él la formula, sino en términos dogmáticos: esa expansión del Derecho Penal que pretende responder a ciertos retos o disfunciones de la globalización se manifiesta aquí en que el hecho típico, como es por todos conocido, se formula respecto de incumplimientos que solo abstractamente suponen una puesta en peligro para el bien jurídicopenal tutelado, salvo que la conformación de este sea tan difuso que permita identificar conductas de las que ex ante pueda formularse un juicio de peligro concreto ${ }^{90}$.

P.M. et al. (coords.), Liber amicorum. Estudios jurídicos en homenaje al Prof. Dr. Dr. h.c. Juan $M^{a}$ Terradillos Basoco, Tirant lo Blanch, Valencia, 2018, pp. 347 y ss.

88 Vid. GARCÍA RIVAS, N.: «Influencia del principio de precaución sobre los delitos contra la seguridad alimentaria», Revista de Derecho Penal y Criminología, $\mathrm{n}^{\circ}$ 15, 2005, pp. 55 y ss.; últimamente, SÁNCHEZ LÁZARO, F.G.: «Deconstruyendo el riesgo permitido. Delitos contra la salud pública, principio de precaución, delitos contra la seguridad vial», Revista Penal México, nº 2, 2011, pp. 75 y ss., 83 y ss.

89 GONZÁLEZ CUSSAC, J.L.: "Apuntes de un Derecho Penal híbrido», en J.M. Silva Sánchez et al. (coords..), Estudios de Derecho Penal: homenaje al profesor Santiago Mir Puig, B. de F., Buenos Aires, 2017, pp. 5 y 6.

90 Vid. CORCOY BIDASOLO, M.: Delitos de peligro y protección de bienes jurídico-penales supraindividuales, Tirant lo Blanch, Valencia, 


\section{Reflexiones finales}

Es a todas luces evidente que la globalización ha supuesto grandes aportes en muchos ámbitos. Pero también ha generado efectos devastadores, incluso en la política criminal, y que se han venido materializando en las últimas décadas.

Respecto a estos últimos, mi preocupación no es que se haya generado un espacio para autorregularse, sino para autoexcluirse penalmente. Autorregularse es, en parte, consustancial al Estado liberal de Derecho, como ya afirmé, $\mathrm{y}$, por tanto, no hay que verlo en todo caso como un efecto perverso de la globalización. Pretender autoexcluirse penalmente sí puede resultar bajo ciertas condiciones insoportable en un Estado democrático de Derecho.

Añado, por igual, que no tengo una opinión negativa del compliance, ni mucho menos. Sí de algunas de las razones que se aducen y de pretendidos efectos que algunos le quieren atribuir, tan atinadamente expuestos por Ferré Olivé y González Cussac ${ }^{91}$. En un reciente trabajo he dejado apuntado la conveniencia de indagar acerca del rendimiento material de los contratos inteligentes (smart contracts) en la implementación de programas de cumplimiento normativo (compliance programs), montados sobre la tecnología de la cadena de bloques (blockchain) en relación con la responsabilidad penal de las personas jurídicas (otra manifestación de la llamada «Blockchain $2.0 »)^{92}$.

1999, passim; MARTÍNEZ-BUJÁN PÉREZ, C.: Derecho Penal económico y de la empresa. Parte General, $5^{\text {a }}$ edic., Tirant lo Blanch, Valencia, 2016, pp. 153 y ss.; MATA Y MARTÍN, R.M.: Bienes jurídicos intermedios y delitos de peligro, Comares, Granada, 1997, passim; SÁNCHEZ GARCÍA DE PAZ, M.I.: El moderno Derecho Penal y la anticipación de la tutela penal, Universidad de Valladolid, Valladolid, 1999, pp. 35 y ss.

91 FERRÉ OLIVÉ, J.C.: «Reflexiones en torno al compliance penal y la ética en la empresa», cit., passim; GONZÁLEZ CUSSAC, J.L.: «El plano político criminal en la responsabilidad penal de las personas jurídicas», cit., p. 98.

92 NAVARRO CARDOSO, F.: «Criptomonedas (en especial, bitcóin) y blanqueo de dinero», Revista Electrónica de Ciencia Penal y Criminología, $\mathrm{n}^{\mathrm{o}} 21,2019$, pp. 38 y 39 . 
La globalización sigue siendo un fenómeno poliédrico y complejo. Entre sus efectos negativos hay que resaltar la deriva que ha tomado el haber propiciado cierta autorregulación (rectius, ciertos desarrollos o modelos). Bien es cierto que está en los genes ideológicos que la han sustentado. Al fin y al cabo, uno de sus principales elementos definidores en sede económica ha sido el dominio ejercido por las grandes corporaciones transnacionales que han acomodado la lex mercatoria a sus intereses, en el mejor y más excepcional de los casos, cuando no el dictado de la misma. De una concepción liberal del mercado, de suerte que sea este quien se autorregule, pero con criterios correctores, se asiste a una concepción ultraliberal, caracterizada por la desaparición de esos criterios que amortiguan sus propias patologías. Es autorregulación en su máxima expresión, económica, y claro está, jurídica.

Bienvenida sea, si se confirma, esta nueva etapa "desglobalizadora", si ella trae consigo la corrección de los efectos más perversos de su proceso inverso ${ }^{93}$. Pretender que en la comisión de hechos delictivos en el seno de una empresa, la responsabilidad penal quede reducida al directivo o empleado, por mor de la existencia de una cultura de cumplimiento (materializada en un modelo de organización y cumplimiento), tal vez sea pretender llevar las supuestas bondades liberales más allá de lo que el Estado social y democrático de Derecho puede y debe tolerar en la gestión del ius puniendi. Sobre todo, teniendo en cuenta que estamos hablando de un modelo fallido, "bendecido" por firmas privadas que "certificaron" su eficacia.

Ese es el gran reto del Derecho Penal en estos tiempos revueltos, aún globalizados: seguir apostando por un sistema penal sometido a unas garantías y unas reglas de imputa-

93 Por cierto, desglobalización fue vocablo candidato a ser palabra del año 2019 de la Fundéu, Fundación del español urgente [En línea: https:// www.fundeu.es/recomendacion/la-candidatas-a-palabra-del-anos2019-de-la-fundeu/. Ultimo acceso: diciembre de 2019]. 
ción, acomodadas a nuevas exigencias y a nuevas perspectivas (provenientes de otros modelos como el Common Law), pero sin que ello suponga, en ningún caso, su desfiguración al punto de hacerlas irreconocibles ${ }^{94}$. Claro que hay que huir de esa propensión al "chauvinismo jurídico" al que se refirió Vogel ${ }^{95}$, que impide como patología apreciar esas nuevas perspectivas. Como también había que huir, por las mismas razones, del "autoconsciente provincialismo" que le atribuye Fletcher a la ciencia penal alemana ${ }^{96}$, y que creo en alguna medida superado, aunque tal vez no tanto por sanación voluntaria (sí manifiestamente en el caso de algunos colegas, también germanos) como por las recetas impuestas desde ciertas instancias supranacionales y países.

Pero tengo para mí que algunas plasmaciones normativas precisan de un mayor esfuerzo argumentativo. Hemos tenido la oportunidad de apreciar algunos ejemplos en este trabajo: castigo de participaciones imprudentes, o de actos preparatorios también imprudentes, insertos, encima, en tipos difusos, porosos, poco rigurosos, en definitiva, con el principio de legalidad penal, o cuando menos con el de taxatividad. Y ya puestos, la culpabilidad no debe ser solo, o debe ser algo más que una ausencia de cultura de cumplimiento. Eso puede servirle a la Sociología o a la Criminología, pero tengo serias dudas de que deba servirle al Derecho, al menos, al Derecho Penal.

94 Dicho de otro modo, no se trata de mantener contra viento y marea la concepción liberal clásica de la política criminal, de modo que lo relevante no es la lucha eficaz contra la criminalidad sino las garantías del justiciable. Así, MIR PUIG, S.: «Constitución, derecho penal y globalización», en S. Mir Puig, M. Corcoy Bidasolo (dirs.), Política criminal y reforma penal, Edisofer, Madrid, 2007, p. 8.

95 VOGEL, J.: «Strafrecht und Strafwissenschaft im internationales und europäisches Rechtsraum», Juristen Zeitung, ${ }^{\circ}$ 1, 2012, pp. 25 y ss., p. 29.

96 FLETCHER, G.: «Die deutsche Strafrechtswissenschaft im Spiegel der echtsvergleichung», en A. Eser, W. Hassemer, B. Burkhardt (edits.), Die deutsche Strafrechtswissenschaft vor der Jahrtausendwende: Rückbesinnung und Ausblick, C.H. Beck, München, 2000, pp. 235 y ss., p. 237. 
Sostiene Ferrajoli que la crisis del Derecho, producto de la globalización, es doble: por su falta de credibilidad y por su impotencia ${ }^{97}$. Con independencia del grado de coincidencia con tal aserto, debemos ser conscientes de que queda camino. No estoy en condiciones ni de dudar acerca de si se ha emprendido ciertamente el camino de vuelta hacia la desglobalización económica. El de la desglobalización jurídica desde luego que no.

\section{Bibliografía}

AMBOS, K.: «Zur Zukunft der deutschen Strafrechtswissenschaft: Offenheit und diskursive Methodik statt selbstbewusster Provinzialität», en K. Tiedemman et al. (edits.), Die Verfassung moderner Strafrechtspflege. Erinnerung an Joachim Vogel, Nomos, Baden-Baden, 2016. https://doi.org/10.5771/9783845276953-321

ANTÓN-MELLÓN, J.; ÁlVAREZ, G.; ROTHSTEIN, P. E.: «Populismo punitivo en España (1995-2015): presión mediática y reformas legislativas», Revista Española de Ciencia Política, $\mathrm{n}^{\circ}$ 43, 2017. https://doi. org/10.21308/recp.43.01

BAUMAN, Z.: La globalización: consecuencias humanas, Fondo de la Cultura Económica, México, 2005

BECK, U.: ¿Qué es la globalización? Falacias del globalismo, respuestas a la globalización, Paidós, Barcelona, 1998

BERDUGO GÓMEZ DE LA TORRE, I.: «El soborno internacional: normas, obstáculos y propuestas», Derecho \& Sociedad, no 52, 2019

BERNAL SARMIENTO, C.E.; CABEZAS CHAMORRO, S.; FORERO CUELLAR, A.; RIVERA BEIRAS, I.; VIDAL TAMAYO, I.: «Estudio Preliminar», en Morrison, W., Criminología, civilización y nuevo orden mundial, Anthropos, Barcelona, 2012

97 FERRAJOLI, L.: «Criminalidad y globalización», cit., p. 302. 
BERNARDI, A.: «El Derecho Penal entre la globalización y multiculturalismo», Revista de Derecho y Proceso Penal, $\mathrm{n}^{\mathrm{o}} 8,2002$

BORJA JIMÉNEZ, E.: «Globalización y concepciones del Derecho Penal», Estudios Penales y Criminológicos, vol. XXIX, 2009

BOZA MARTÍNEZ, D.: La expulsión de personas extranjeras condenadas penalmente, Aranzadi, Cizur Menor, 2016

BUSTAMANTE DONAS, J.: «La cuarta generación de derechos humanos en las redes digitales: segundos pensamientos», Telos: Cuadernos de comunicación e innovación, $\mathrm{n}^{\circ}$ 85, 2010 [En línea: https://telos.fundaciontelefonica.com]

BUSTOS RUBIO, M.: Aporofobia y delito. La discriminación socioeconómica como agravante (art. $22.4^{a} \mathrm{CP}$ ), Bosch, Barcelona, 2020. https://doi.org/10.2307/j.ctv14t46vn

CAPELLA HERNÁNDEZ, J.R.: Fruta prohibida. Una aproximación histórico-teorética al estudio del derecho y del

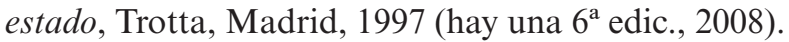

CAPELLA HERNÁNDEZ, J.R.: «Estado y derecho ante la mundialización: aspectos y problemáticas generales», Estudios de Derecho Judicial, nº 16, 1999

CORCOY BIDASOLO, M.: Delitos de peligro y protección de bienes jurídico-penales supraindividuales, Tirant lo Blanch, Valencia, 1999

CORTINA ORTS, A.: Aporofobia, el rechazo al pobre. Un desafío para la democracia, Paidós, Barcelona, 2017

DE GIORGI, A.: «Control de la inmigración, post-fordismo y menor elegibilidad» Crítica penal y poder, $\mathrm{n}^{\circ}$ 2, 2012 DEMETRIO CRESPO, E.: «El significado político del Derecho Penal económico», en E. Demetrio Crespo (dir.), Crisis financiera y Derecho Penal Económico, B de F, Buenos Aires, 2014

DÍAZ, T.: «La pandemia provoca la mayor reducción de $\mathrm{CO}_{2}$ de la historia», Diario elEconomista.es, 30 de abril de 2020 [En línea: https://www.eleconomista.es] 
DOMINGO OSLÉ, R.: ¿Qué es el Derecho Global?, Consejo General del Poder Judicial, Madrid, 2007 (hay una $2^{a}$ edic., Aranzadi, Cizur Menor, 2008)

DONDE MATUTE, J.: «Elementos del Common Law en el Derecho Penal Internacional», Revista Penal México, $\mathrm{n}^{\circ} 3,2012$

DONINI, M.: «El ciudadano extracomunitario: de "objeto material" a "tipo de autor" en el control penal de la inmigración», Revista Penal México, no 4, 2013

FERRAJOLI, L.: «Criminalidad y globalización», Boletín Mexicano de Derecho Comparado, $\mathrm{n}^{\circ}$ 115, 2006

FERRAJOLI, L.: «Criminología, crímenes globales y Derecho Penal: el debate epistemológico en la Criminología contemporánea», Revista Crítica Penal y Poder, $\mathrm{n}^{\circ}$ 4, 2013

FERRÉ OLIVÉ, J.C.: «El Plea Bargaining, o cómo pervertir la justicia penal a través de un sistema de conformidades low cost», Revista Electrónica de Ciencia Penal y Criminología, $\mathrm{n}^{\mathrm{o}}$ 20, 2018

FERRÉ OLIVÉ, J.C.: «Instrumentos internacionales en la lucha contra la financiación del terrorismo», en J.C. Ferré Olivé, A.I. Pérez Cepeda (dirs.), Financiación del terrorismo, Tirant lo Blanch, Valencia, 2018

FERRÉ OLIVE, J.C.: «Reflexiones en torno al compliance penal y la ética en la empresa», Revista Penal, $\mathrm{n}^{\circ} 44$, 2019

FISCHER-LESCANO, A.; GUNTHER TEUBNER, G.: «Regime-Collisions: The Vain Search for Legal Unity in the Fragmentation of Global Law», Michigan Journal of International Law, vol. 25, 2004

FLETCHER, G.: «Die deutsche Strafrechtswissenschaft im Spiegel der echtsvergleichung», en A. Eser, W. Hassemer, B. Burkhardt (edits.), Die deutsche Strafrechtswissenschaft vor der Jahrtausendwende: Rückbesinnung und Ausblick, C.H. Beck, München, 2000 
FRIEDMAN, T.: La tierra es plana. Breve historia del mundo globalizado del siglo XXI, Ediciones Martínez Roca, Madrid, 2006

GALÁN MUÑOZ, A.: Fundamentos y límites de la responsabilidad penal de las personas jurídicas tras la reforma de la LO 1/2015, Tirant lo Blanch, Valencia, 2017

GARCÍA ESPAÑA, E.: «La expulsión como sustitutivo de la pena de prisión en el Código Penal de 2015», Revista electrónica de Ciencia Penal y Criminología, $\mathrm{n}^{\circ}$ 18,2016

GARCÍA ESPAÑA, E.: «Más inmigración, menos delincuencia», Crítica penal y poder, $\mathrm{n}^{\circ}$ 18, 2019

GARCÍA RIVAS, N.: «Influencia del principio de precaución sobre los delitos contra la seguridad alimentaria», Revista de Derecho Penal y Criminología, $\mathrm{n}^{\circ}$ 15, 2005

GONZÁLEZ CUSSAC, J.L.: «Apuntes de un Derecho Penal híbrido», en J.M. Silva Sánchez et al. (coords..), Estudios de Derecho Penal: homenaje al profesor Santiago Mir Puig, B. de F., Buenos Aires, 2017

GONZÁLEZ CUSSAC, J.L.: «El plano político criminal en la responsabilidad penal de las personas jurídicas», en A. Matallín Evangelio (dir.), Compliance y prevención de delitos de corrupción, Tirant lo Blanch, Valencia, 2018

GONZÁLEZ CUSSAC, J.L.: «La eficacia eximente de los programas de prevención de delitos», Estudios Penales y Criminológicos, vol. XXXIX, 2019. https://doi. org/10.15304/epc.39.6039

GRACIA MARTÍN, L.: "Criminalidad de la globalización y Derecho penal», en C.M. Romeo Casabona (ed.), Biotecnología, desarrollo y justicia, Comares, Granada, 2008

GRACIA MARTÍN, L.: «Crítica de las modernas construcciones de una mal llamada responsabilidad penal de la persona jurídica», Revista Electrónica de Ciencia Penal y Criminología, $\mathrm{n}^{\circ} 18,2016$, pp. 1 y ss. 
GUIDDENS, A.: Consecuencias de la modernidad, Alianza, Madrid, 2004

GUISASOLA LERMA, C.: «Reformas penales y tendencias político-criminales en materia de inmigración», $L a$ Ley Penal, $\mathrm{n}^{\circ}$ 67, 2010

HERNÁNDEZ, E.: «Un multimillonario advierte: "Todos lo sabemos, este capitalismo está muerto"», Postpolítica [blog], 17 de octubre de 2019

HORTAL IBARRA, J.C.: «Tutela de las condiciones laborales y reformas penales: ¿el ocaso del Derecho Penal del Trabajo?», Revista de Derecho Penal y Criminología, $\mathrm{n}^{\circ} 20,2018$

IGLESIAS VÁZQUEZ, M.A.: «Globalización, globalización jurídica, Global Law y Derecho Internacional Privado», Cuadernos de Derecho Transnacional, vol. 9, $\mathrm{n}^{\mathrm{o}}$ 1, 2017. https://doi.org/10.20318/cdt.2017.3619

LEÓN ALAPONT, J.: «Criminal compliance: análisis de los arts. 31 bis 2 a 5 CP y 31 quater CP», Revista General de Derecho Penal, $\mathrm{n}^{\mathrm{o}}$ 31, 2019

MARCILLA CÓRDOBA, G.: «Desregulación, Estado social y proceso de globalización», Doxa, Cuadernos de Filosofía del Derecho, $\mathrm{n}^{\mathrm{o}}$ 28, 2005. https://doi. org/10.14198/DOXA2005.28.16

MARTÍNEZ-BUJÁN PÉREZ, C.: Derecho Penal económico y de la empresa. Parte General, $5^{\text {a }}$ edic., Tirant lo Blanch, Valencia, 2016

MARTÍNEZ ESCAMILLA, M.: «La criminalización de la solidaridad», Crítica penal y poder, $\mathrm{n}^{\circ}$ 18, 2019

MATA Y MARTÍN, R.M.: Bienes jurídicos intermedios y delitos de peligro, Comares, Granada, 1997

MIR PUIG, S.: «Constitución, derecho penal y globalización», en S. Mir Puig, M. Corcoy Bidasolo (dirs.), Política criminal y reforma penal, Edisofer, Madrid, 2007

MIRÓ LLINARES, F.: «Política comunitaria de inmigración y Política criminal en España», Revista Electrónica de Ciencia Penal y Criminología, nº 10, 2008 
MORRISON, W.: Criminología, civilización y nuevo orden mundial, Anthropos, Barcelona, 2012

NAVARRO CARDOSO, F.: «El Derecho penal del riesgo y la idea de seguridad. Una quiebra del sistema sancionador», en F. Pérez Álvarez (ed.), Serta. In Memoriam Alexandri Baratta, Servicio de Publicaciones de la Universidad de Salamanca, Salamanca, 2004

NAVARRO CARDOSO, F.: «El Código Penal de la seguridad e inmigración (consideraciones criminológicas y político-criminales)», en M.J. Rodríguez Mesa, L.R. Ruiz Rodríguez (coords.), Inmigración y sistema penal. Retos y desafíos para el siglo XXI, Tirant lo Blanch, Valencia, 2006

NAVARRO CARDOSO, F.: «Vallejo Nágera, "los niños perdidos del Franquismo" y los crímenes contra la humanidad”, en J.C. Ferré Olivé (dir.), El derecho penal de la posguerra, Tirant lo Blanch, Valencia, 2016

NAVARRO CARDOSO, F.: «El delito de contratación ilegal del art. 311 bis CP: un nuevo despropósito, y un viejo vicio, legislativo», en P.M. de la Cuesta Aguado et al. (edits.), Liber Amicorum. Estudios Jurídicos en Homenaje al Prof. Dr. Dr. h.c. Juan $M^{a}$ Terradillos Basoco, Tirant lo Blanch, Valencia, 2018

NAVARRO CARDOSO, F.: "Criptomonedas (en especial, bitcóin) y blanqueo de dinero», Revista Electrónica de Ciencia Penal y Criminología, no 21, 2019

NIETO, A.: Una introducción al derecho, Tirant lo Blanch, Valencia, 2019

NIETO MARTÍN, A.: «Derecho penal y Constitución en la era del Global Law», en S. Mir Puig, M. Corcoy Bidasolo (dirs.), Garantías constitucionales y Derecho penal europeo, Marcial Pons, Madrid, 2012

ORTIZ DE URBINA GIMENO, I.: "Cultura de cumplimiento y exención de responsabilidad de las personas jurídicas», Revista Internacional de Transparencia e Integridad, $\mathrm{n}^{\circ}$ 6, 2018 
PÉREZ LUÑO, A.E.: «Las generaciones de derechos humanos», en F. J. Ansuátegui Roig, J. Rodríguez Uribes, G. Peces-Barba, E. Fernández García, Historia de los derechos fundamentales, vol. 4, t. I, Dykinson, Madrid, 1998

PERRON, W.: «Europäische und transnationale Strafrechtspflege als Herausforderung für eine modern Strafrechtdogmatik», en K. Tiedemman et al. (edits.), Die Verfassung moderner Strafrechtspflege. Erinnerung an Joachim Vogel, Nomos, Baden-Baden, 2016. https:// doi.org/10.5771/9783845276953-307

PRITTWITZ, C.: Strafrecht und Risiko. Untersuchungen zur Krise von Strafrecht und Kriminalpolitik in der Risikogesellschaft, Klostermann, Frankfurt am Main, 1993. https://doi.org/10.3196/9783465025870

PRITTWITZ, C.: «Sociedad del riesgo y Derecho penal», en L. Arroyo Zapatero et al. (coords.), Crítica y justificación del derecho penal en el cambio de siglo: el análisis crítico de la Escuela de Frankfurt, Ediciones de la Universidad de Castilla-La Mancha, Cuenca, 2003

PRITTWITZ, C.: «La función del Derecho Penal en la sociedad globalizada del riesgo: defensa de un rol necesariamente modesto», en E. Pérez Alonso et al. (edits.), Derecho, globalización, riesgo y medio ambiente, Tirant lo Blanch, Valencia, 2012

QUINTERO OLIVARES, G.: «La globalización y el Derecho Penal: un cajón de sastre conceptual», en A. Galán Muñoz, S. Mendoza Calderón (dirs.), Globalización y lucha contra las nuevas formas de criminalidad transnacional, Tirant lo Blanch, Valencia, 2019

REAL ACADEMIA ESPAÑOLA: Diccionario de la lengua española, 23. ${ }^{a}$ ed., 2019 [versión 23.3 en línea: https:// dle.rae.es]

REBOLLO VARGAS, R.: «A vueltas con el Derecho penal de la peligrosidad» en P.M. de la Cuesta Aguado et al. (coords.), Liber amicorum. Estudios jurídicos en 
homenaje al Prof. Dr. Dr. h.c. Juan $M^{a}$ Terradillos Basoco, Tirant lo Blanch, Valencia, 2018

ROBERTSON, R.: «Glocalización: tiempo-espacio y homogeneidad-heterogeneidad», en J.C. Monedero Fernández-Gala (coord.), Cansancio del Leviatán: problemas políticos de la mundialización, Trotta, Madrid, 2003

SAMPEDRO, J.L.: El mercado y la globalización, Destino, Barcelona, 2002

SÁNCHEZ GARCÍA DE PAZ, M.I.: El moderno Derecho Penal y la anticipación de la tutela penal, Universidad de Valladolid, Valladolid, 1999

SÁNCHEZ LÁZARO, F.G.: «Deconstruyendo el riesgo permitido. Delitos contra la salud pública, principio de precaución, delitos contra la seguridad vial», Revista Penal México, $\mathrm{n}^{\circ}$ 2, 2011

SCHÜNEMANN, B.: «Das Strafrecht im Zeichen der Globalisierung», Goltdammer's Archiv für Strafrecht (5), 2003

SILVA SÁNCHEZ, J.M.: La expansión del Derecho penal. Aspectos de la política criminal en las sociedades posindustriales, $2^{\mathrm{a}}$ edic., Civitas, Madrid, 2001, pp. 81 y ss. (hay una $3^{\text {a }}$ edic., Edisofer, Buenos Aires, 2011)

SPANGERBER BOLÍVAR, M.: «El Derecho penal del riesgo globalizado. Desafíos para un Derecho penal legítimo y trasnacionalmente efectivo», Revista de Derecho (Publicación de la Facultad de Derecho de la Universidad Católica de Uruguay), nº 15, 2017. https:// doi.org/10.22235/rd.v1i15.1377

STEGER, M.B.: Globalización. Una breve introducción, Antoni Bosch editor, Barcelona, 2019

STIGLITZ, J.E.: El malestar en la globalización, Taurus, Madrid, 2002

TERRADILLOS BASOCO, J.: «Globalización, administrativización y expansión del Derecho penal económico», Nuevo Foro Penal, ${ }^{\circ}$ 70, 2006 
TERRADILLOS BASOCO, J.: «El Derecho penal como estrategia de exclusión: la respuesta punitiva a la inmigración», Revista Penal México, n ${ }^{\circ}$ 3, 2012

TERRADILLOS BASOCO, J.: «Un sistema penal para la aporofobia», en G. Portilla Contreras, F. Velázquez Velázquez (dirs.), Un juez para la democracia. Libro Homenaje Perfecto Andrés Ibáñez, Dykinson, Madrid, 2019. https://doi.org/10.2307/j.ctv103xbt5.21

TWINING, W.: Derecho y Globalización, Siglo del Hombre, Bogotá, 2003

VIDAL TAMAYO, I.A.: «Recensión a Criminología, civilización y nuevo orden mundial», de W. Morrison, Anthropos, Barcelona, 2012, en Revista Crítica Penal y Poder, $n^{\circ}$ 3, 2012

VOGEL, J.: «Derecho penal y globalización», Anuario de la Facultad de Derecho de la Universidad Autónoma de Madrid, no 9, 2005

VOGEL, J.: «Strafrecht und Strafwissenschaft im internationales und europäisches Rechtsraum», Juristen Zeitung, $\mathrm{n}^{\circ}$ 1, 2012. https://doi. org/10.1628/002268812798860283

ZAFFARONI, E.R.; DIAS DOS SANTOS, I.: La nueva crítica criminológica. Criminología en tiempos de totalitarismo financiero, Ediar, Buenos Aires, 2019

ZÚÑIGA RODRÍGUEZ, L.: «Trata de seres humanos y criminalidad organizada transnacional: problemas de política criminal desde los derechos humanos», Estudios Penales y Criminológicos, $\mathrm{n}^{\circ} 38,2018$. https://doi. org/10.15304/epc.38.4582 